\title{
Uluslararası Öğrencilerin Sosyo-Ekonomik Problemleri ve Çözüm Önerileri (Sakarya Üniversitesi Örneği)*
}

Socio-Economic Problems of International Students and Some Remedies (Sakarya University Case)

\section{Fatih Yardımcıoğlu}

\section{Furkan Beşel}

\section{Fatih Savaşan}

\section{$\ddot{O} z$}

Küreselleşmenin eğitim alanında gerçekleştirdiği değişimin sonucu uluslararası öğrenci dolaşımının boyutları artmıştır. Uluslararası öğrencilerin gittikleri ülke ekonomilerine sağladıkları katkılar yanında sağladığı prestij ve beşeri sermayeyi oluşturan taraf olmanın sağladığı sosyokültürel avantajlar dolayısıyla tüm ülkeler bu gelişmeden pay alma çabası içerisine girmiştir. Öte yandan uluslararası öğrencilerin uyum sorunları üzerinde önemle durulması gereken bir alanı oluşturmaktadır. Bu çalışmanın amacı Sakarya

\footnotetext{
* Bu çalışma UDEF (Uluslararası Öğrenci Dernekleri Federasyonu tarafından 6-8 Kasım 2015 tarihinde İstanbul' da organize edilen "Uluslararası Öğrenci Sempozyumu'nda sunulan "Yabancı Uyruklu Lisans ve Lisans Üstü Öğrencilerin Sosyo-Ekonomik Problemleri: Sakarya Üniversitesi Örneği” isimli bildirilerin gözden geçirilerek genişletilmiş halidir.
}

Doç. Dr., Sakarya Üniversitesi, Siyasal Bilgiler Fakültesi, Maliye Bölümü, fatihyardimcioglu@gmail.com.

Arş. Gör. Dr., Sakarya Üniversitesi, Siyasal Bilgiler Fakültesi, Maliye Bölümü, fbesel@sakarya.edu.tr.

Prof. Dr., Sakarya Üniversitesi, Siyasal Bilgiler Fakültesi, Maliye Bölümü, fsavasan@ sakarya.edu.tr.

Çalışmaya katkılarından dolayı Maliye Bölümü öğretim elemanı Arş. Gör. Uğur Uyğun'a teşekkür ederiz.

Bu makale iThenticate sistemi tarafından taranmıştır.

Makale Gönderim Tarihi: 01.08.2016

DOI: 10.17550/akademikincelemeler.308940 
Üniversitesi'nde öğrenim gören uluslararası öğrenciler örneği üzerinden sosyo-ekonomik problemlerinin tespit edilmesidir. Anket yönteminden ve yarı yapılandırılmış mülakat tekniğinden yararlanılarak yapılan çalışmada ilk olarak öğrencilerin Türkiye'yi tercih nedenleri araştırılmış, daha sonra öğrencilerin sosyo-ekonomik problemleri arkadaşlık, sağlık, kültürel, ekonomik, psikolojik, akademik ve sosyal sorunlar başlıkları altında araştırılmıştır. Çalışmada öğrencilerin arkadaşlık, sağlık, kültürel, ekonomik, psikolojik, akademik ve sosyal sorunlarla ilgili yaşadığı problemlere karşı çözüm önerileri sunulmuştur.

Keywords: Yabancı Uyruklu (Uluslararası) Öğrenciler, Sosyo-Ekonomik Problemler, Öğrencilerin Problemleri. 


\begin{abstract}
Thanks to the changes brought about by globalization we observe considerable increase in the size of student exchange amongst countries. Countries try to attract more international students not only due to their likely contributions to national economies but also prestige and added value created by being human capital accumulating country. On the other hand, the problems faced by international students should be carefully studied. This paper aims to determine those socioeconomic problems using Sakarya University case. Utilizing a survey questionnaire and semi-structured interviews, it first unveils why students choose Turkey to study and then identifies issues faced under the categories health, culture, economic, psychologic, academic and social. This study also puts forward remedies to the problems to some extent.
\end{abstract}

Keywords: Foreign/International Students, Socio-Economical Problem 


\section{Giriș}

Küreselleşme olgusu birçok alanda olduğu gibi eğitim alanında da hız11 değişimleri beraberinde getirmektedir ve bu değişimler sonucunda uluslararası eğitim pazarı da giderek büyümektedir. Uluslararası öğrenci dolaşımı ise bu pazarın önemli bir ayağını oluşturmaktadır. Uluslararası öğrenci dolaşımının boyutları giderek artmaktadır ve artan boyutu ile de ekonomik bir sektör haline dönüşmüştür. (Kıroğlu vd., 2010). Ekonomik bir sektör olarak uluslararası öğrenci dolaşımından ülkeler daha fazla faydalanmak ve mevcut paylarını artırmak istemektedir. Bu amaçla da eğitim sitemlerinde uluslararası öğrencilere yönelik yenilikler oluşturmaktadır.

Gelişmekte olan ülkeler ve kendi kültür havzasında yer alan ülke halkları arasında popülaritesi günden güne artan Türkiye bir çok alanda olduğu gibi eğitimde de özellikle de yükseköğrenimde bir destinasyon haline gelmeye başlamıştır. Bunda Türkiye'nin 2000'li yıllardan sonra sağladığı ve halen devam eden göreli ekonomik ve siyasi başarısının yanında, 2010'dan sonra üniversitelerin uluslararasılaşmasına gittikçe daha fazla önem vermesinin de etkisi vardır. TÜBİTAK ${ }^{1}$, Yurtdışı Türkler ve Akraba Topluluklar Başkanlığı (YTB), YÖK, İslam Kalkınma Bankası (IDB), Milli eğitim Bakanlığı, devletler arası anlaşmalar, Türk Ulusal Ajansı, Mevlana Programı, Comenius Okul eğitim Program1, Erasmus Program1, Leonardo Da Vinci Program1, Grundtvig Programı (yetişkin eğitimi), Türkiye Diyanet Vakfı, Türk Silahli kuvvetleri ve Emniyet Genel Müdürlüğü, bazı Sivil Toplum Kuruluşları (STK) ve özel üniversiteler tarafindan başlatılan programlar sayesinde son yıllarda Dünya’nın bir çok ülkesinden kaliteli öğrenciler Türkiye'ye eğitim için gelmektedir.

Bunların yanı sıra TÜBİTAK doktora aşamasında olan ve doktorasını yeni tamamlamış genç araştırmacıların Türkiye'de araştırma yapmaları için de burs vermektedir. TÜBİTAK ayrıca araştırmacıların

12215 Uluslararası Öğrenciler İçin Lisansüstü Burs Programı 05.09.2015 ve 245 sayılı TÜBİTAK Bilim Kurulu kararı ile yürürlükten kaldırılmışır. Bu kapsamda 2215 programına 2015 yılı Eylül ayından itibaren başvuru alınmamakta fakat programdaki mevcut bursiyerlerin burs işlemleri sürdürülmektedir. 
Türkiye'ye araştırma, eğitim ve çalıştay gibi faaliyetler için gelmelerini sağlamaya yönelik programlar da yürütmektedir.

YTB tarafindan yürütülen Türkiye Bursları kapsamında, online başvuru ile başvuran adayları ön elemeye tabi tutan kurum ardından yüze yakın ülkede mülakat sürecini de işleterek "en iyi” öğrencileri seçmeyi hedeflemektedir. YÖK ile yapılan protokolle üniversitelerde yabancı öğrencilerle ilgilenecek ofisler de açmayı hedefleyen ${ }^{2}$ YTB, Türkiye'nin eğitimde dışa açılma çabasında çıtayı yükseltmiştir. YTB tarafından yürütülen Türkiye Bursları programının dört bin civarındaki kontenjanı için yüz bine yakın başvuru alınması sadece Türkiye'nin eğitimde artan cazibesinin yanı sıra Türkiye Burslarının başarısına da işaret ettiği belirtilebilir.

YÖK ise $A B$ ülkeleri ile yürütülen Erasmus programına ilave olarak Mevlana programını başlatmıştır. Böylece üniversitelere Dünya'daki herhangi bir ülkenin üniversitesi ile öğrenci (ve öğretim üyesi) değişimini başlatma imkânı tanımıştır. Yükseköğrenimde değişimi AB dışına taşıyan Mevlana programını Türkiye'nin değişen vizyonunun bir yansıması olarak görmek hatalı olmayacaktır.

Resmi kurumların yanında STK'lar da ${ }^{3}$ Türkiye'de öğrenim görmek üzere uluslararası öğrencilere burs imkânı sağlamaktadır. Türkiye Diyanet Vakfı da özellikle lise seviyesinde uluslararası öğrencilere yönelik programlar uygulayan bir diğer kuruluştur. Vakıf tarafından 1992-2011 yılları arasında örgün eğitim almak üzere ülkemize getirilen toplam öğrenci sayısı 3.115'tir. Bunların dışında Bilkent ve Bahçeşehir üniversiteleri gibi bazı vakıf üniversiteleri de uluslararası öğrencilere yönelik burs ve çeşitli destekler vermektedir (KB, 2014: 87).

\footnotetext{
$2 \mathrm{Bu}$ çalışmada yapılan anket ve mülakatlarda yabancı uyruklu öğrencilerin sorunlarının çözümünde üniversitelerde bir ofisin bulunmasının gerekliliği ön plana çıkmıştır. $\mathrm{Bu}$ tarz bir ofisin açılmasının öğrencilerin sorunlarının ilk elden ve daha hızlı çözümünde etkili olacağı, programdan beklenen katkıyı ise artıracağı belirtilebilir.

3 Uluslararası öğrencilere yönelik faaliyetlerde bulunan STK'ların birçoğu 2012 y1lında UDEF (Uluslararası Öğrenci Dernekleri Federasyonu) bünyesinde bir araya toplanmıştır. UDEF, 14 Aralık 2012'de 11 dernek tarafından kurulmuştur. Hedef kitlesi Türkiye'de eğitim gören uluslararası öğrenciler olan üye derneklerin sayısı kısa zamanda 49 şehirde 57 sayısına ulaşmıştır. UDEF ile ilgili ayrıntılı bilgiler için bknz: www.udef.org.tr.
} 
Uluslararası düzeyde öğrenci değişimini öngören, Mevlana Programı, Comenius Okul eğitim Programı, Erasmus Programı, Leonardo Da Vinci Programı, Grundtvig Programı (yetişkin eğitimi) gibi programlar vasıtasıyla da son yıllarda uluslararası öğrenciler Türkiye’ye belli bir süre eğitim almak amacıyla gelmektedir.

YÖK ve YTB arasında Mart 2014 tarihinde imzalanan protokol ile "Türkiye Bursluları Koordinasyon Ofisleri” kurulmuştur. Bu ofislerin burslu öğrencilerin işlemlerinin yürütülmesinin yanı sıra tüm uluslararası öğrencilere yönelik rehberlik faaliyetlerini gerçekleştirmesi öngörülmektedir. Bunun yanı sıra uluslararası öğrencilerin barınmalarına yönelik olarak YURTKUR ile işbirliği içinde yüksek lisans ve doktora öğrencileri için daha iyi şartlarda barınma imkânı sunan yüksek ücretli yurtlarda Türkiye Bursları kapsamında desteklenen öğrenciler için kontenjan ayrılmaya başlanmıştır (KB, 2014: 87).

Bu gelişmeler neticesinde 2000'li yılların ortalarından önce İngilizce eğitim veren birkaç üniversiteyle sınırlı kalan Türkiye'nin yabancı öğrenci varlığı günümüzde üniversitelerin tamamına yansımış durumdadır. Dahası yabancı öğrencilerin çeşitliliği de artık görünür olmaya başlamıştır. Türkiye'nin cazibesinin artması ve eğitimde göreli iyileşme için kuşkusuz lisans ve özellikle lisansüstü eğitim için Türkiye'ye gelen yabancı öğrenci sayısı iyi bir göstergedir. Zira bireylerin en rasyonel davrandıkları alanlardan biri lisans özellikle de lisansüstü eğitimdir (Savaşan, 2015).

Teorik olarak meseleye bakıldığında kişi bir programa yerleşirken beklediği yaşam boyu getiriyi (gelir, statü vs.) eğitim süresince katlanacağı gözlenen (harç, yemek, barınma vs.) ve gözlenemeyen (belirsizliğin yol açtığı kaygı, aile özlemi, kültürel şok vs.) maliyetler ile kıyaslar. Eğer getiri yüksekse programa yerleşir. Yabancı bir ülkede eğitim almanın ekonomik ve psikolojik maliyetleri çok daha yüksek olmasına rağmen Afrika'dan veya Latin Amerika'dan, Orta Asya'dan veya Balkanlardan Türkiye'ye eğitim için gelenlerin sayısının artması Türkiye'nin ve Türkiye'de alacağ 1 eğitimin cazibesinin arttığını göstermektedir. Ayrıca aksanlı Türkçesi ile minibüste para üstü soran bir siyahi bayan öğrenci, kampüs camiinde müezzinlik yapan Sudanlı bir erkek öğrenci veya yüksek lisans dersinde İsrail'le ilgili farklı bir pers- 
pektif sunan bir Kolombiyalı öğrenci aslında sadece üniversitelere değil Türkiye'ye renk getirmektedir (Savaşan, 2015).

Türkiye özellikle tarihi ve kültürel anlamda ilişkili olduğu ülke öğrencilerinin eğitim görmek istediği ülkelerin başında gelmektedir. Dolayısıyla son yıllarda Türkiye'de ve birçok üniversitede olduğu gibi Sakarya Üniversitesi'nde de eğitim gören uluslararası öğrencilerin sayısı giderek artmaktadır. Ancak bu öğrencilerin tıpkı diğer ülkelerde eğitim gören uluslararası öğrenciler gibi birçok sosyo-ekonomik sorunları mevcuttur. Bu sorunların başında dil ile ilgili sorunlar gelmektedir. Bunun yanı sıra arkadaşlıkla, sağlık ve kültürle ilgili sorunlar, ekonomik, psikolojik, akademik ve sosyal sorunlar, barınma, yemeiçme sorunları, memleket özlemi, kültürel farklılıklarla ilgili sorunlar gelmektedir. Bazı öğrencilerin sorunları geldikleri ülkelere göre değişmekle beraber öğrencilerin birçok sorunu ise ortaktır.

$\mathrm{Bu}$ çalı̧̧manın amacı Sakarya Üniversitesi'nde öğrenim gören uluslararası lisans ve lisansüstü öğrencilerin sosyo-ekonomik problemlerinin tespit edilmesidir. Uluslararası öğrencilerin sosyo-ekonomik problemlerinin tespit edilmesi ve bu sorunların giderilmesine yönelik tedbirlerin alınması bu amaçla oluşturulan programların etkinliğini artıracaktır.

Yapılan çalışmada sosyal bilimlerde sıklıkla kullanılan anket yönteminden ve yarı yapılandırılmış mülakat tekniğinden yararlanılmıştır. Hazırlanılan ankette, araştırılmak istenen konunun amacını en iyi yansitacak sorulara yer verilmiştir. Anket formunda genellikle 5'li likert ölçeğe göre hazırlanmış sorular yer almaktadır. Ayrıca ankette katılımcıların demografik özelliklerini ölçmeye yönelik sorular da yer almaktadır. Yarı yapılandırılmış mülakat tekniğinde ise öğrencilere anketteki ana konularla ilgili yaşadıkları ve karşılaştıkları problemlerin neler olduğu sorulmuş ve öğrencilerden gelen cevaplar anket cevapları ile birleştirilerek yorumlanmıştır.

Muhtemel hataları düzeltebilme ve anketten beklenen amacın gerçekleştirilmesi amacıyla her iki yöntem için pilot bir uygulama yapılmış, ilgili uzmanlarla görüşülmüş ve daha sonra anket Sakarya Üniversitesi'nde lisans ve lisansüstü eğitimine devam eden öğrencilere uygulanmıştır. Anketlerde elde edilen veriler SPSS programı kullanılarak analiz edilmiştir. 
“Uluslararası öğrencilerin sosyo-ekonomik problemleri nelerdir?" sorusu bu çalışmanın araştırma sorusudur. Bu çerçevede daha önceden yapılan çalışmalarda elde edilen bulgulara dayanarak bu öğrencilerin dil ile, arkadaşlıkla, sağlık ve kültürle ilgili sorunları, ekonomik, psikolojik, akademik ve sosyal sorunları nelerdir? şeklinde araştırma soruları ile sorunların analizi yapılmıştır.

$\mathrm{Bu}$ çalışmanın temel hipotezi ise "Uluslararası öğrencilerin sosyo-ekonomik problemleri vardır" şeklinde oluşturulmuştur.

Bu bağlamda çalışmanın hipotezleri şu şekilde gösterilebilir;

$\checkmark$ H1: Uluslararası öğrencilerin dil ve iletişim ile ilgili sorunları vardır.

$\checkmark$ H2: Uluslararası öğrencilerin arkadaşlıkla ile ilgili sorunları vardır.

$\checkmark$ H3: Uluslararası öğrencilerin sağlıkla ilgili sorunları vardır.

$\checkmark$ H4: Uluslararası öğrencilerin kültürle ilgili sorunları vardır.

$\checkmark$ H5: Uluslararası öğrencilerin ekonomik sorunları vardır.

$\checkmark$ H6: Uluslararası öğrencilerin psikolojik sorunları vardır.

$\checkmark$ H7: Uluslararası öğrencilerin akademik sorunları vardır.

$\checkmark$ H8: Uluslararası öğrencilerin sosyal sorunları vardır.

Dört bölümden oluşan bu araştırmanın ilk bölümünde eğitimde ve araştırmada uluslararası öğrencilerin önemi anlatılmıştır. İkinci bölümünde uluslararası öğrenci hareketliğinin Türkiye ve dünyadaki gelişiminden bahsedilmiştir. Üçüncü bölümünde uygulamalı çalışmaların bulgularına yer verilmiştir. Dördüncü bölümde uluslararası öğrencilerin sosyo-ekonomik problemlerine ilişkin Sakarya özelinde yapılmış saha araştırması sonuçlarına yer verilmiştir. Sonuç bölümünde araştırma sonucunda elde edilen bulgular sunulmuş ve değerlendirme bölümünde ise bu bulgular değerlendirilmiştir.

\section{Eğitim ve Araştırmada Yabancı Öğrencilerin Önemi}

Türkiye kişi başı geliri on bin doların biraz üzerinde "orta gelir düzeyinde" olan bir ülkedir. Orta gelir grubunda çok uzun süre oyalanan ve bir türlü bir üst gelir gurubuna çıkamayan birçok ülkenin varlığ 1 göz önüne alındığında Türkiye "orta gelir tuzağı" denilen bu duruma 
düşmemek için tedbirler almaktadır. Türkiye geliri 800 milyar dolar civarındaki bir ülkeden beklenemeyecek cömertlikte burs ve araştırma imkânları sunarak yabancı öğrenci ve araştırmacı çekmeye gayret etmesi alınan tedbirlerden bir tanesi olarak belirtilebilir. Türkiye'nin 2023 Hedeflerine ulaşması kuşkusuz yeni bir sıçrama yapmasını zorunlu kılmaktadır ve bu sıçramanın yapılamasında ise araştırma ve geliştirme (AR-GE) faaliyetleri büyük öneme sahiptir. Araştırma ve geliştirme faaliyetlerinde ise iyi yetişmiş beşeri sermayenin katkısı son derece önemlidir. (Savaşan, 2015)

Tecrübeli araştırmacıların Türkiye'ye geçici veya sürekli gelerek çalışmalarını burada yürütmeleri araştırma kültürünün yayılmasına yardımcı olacaktır. Türkiye'nin yurtdışına verilen beyin göçünü tersine çevirmesi gerekir. Bu yönde TÜBITTAK ve üniversitelerin attıkları adımlar orta vadede meyvelerini verecektir. Diğer taraftan yeni beyinlerin kazanılması gerekir. Afrika'dan Orta Asya'ya ümit vadeden gençlerin gittikçe daha çok sayıda Türkiye'ye yönelmeleri de ümitli olmamıza yol açmaktadır. Türkiye'nin birçok farklı programla bu faaliyetleri desteklemeye başlaması önemli ve yerinde bir adımdır (Savaşan, 2015).

Türkiye'de lisans veya lisansüstü çalışmasını yapan öğrencilerin Türkiye'ye katacağı artı değer çok önemlidir. Öğrenciler eğitimleri sonunda ister Türkiye'de kalsınlar isterlerse ülkelerine dönsünler bu artı değerin daima oluşacağı belirtilebilir. Zira Afrikalı bir öğrenci uluslararası ticaret eğitimini aldıktan sonra Türkiye'nin ticaretine Türkiye'de kalmakla da ülkesine dönmekle de yardımcı olabilir. Bu yüzden mobiliteyi önleyen, bursiyerlerin eğitim sonrası kararlarına ipotek koymaya çalışan burs programlarından kaçınmak önemli ve gereklidir. Baştan aşırı sınırların konulması genç beyinlerin Türkiye'yi tercihini olumsuz etkileyebilir. Bilinmelidir ki Türkiye'de eğitimini tamamlayan yabancı öğrenciler ticarette ve kültürde, akademide ve sanatta sadece kendi ülkelerinin değil aynı zamanda Türkiye'nin de birer değeridirler. Eğitim ve araştırmada yabancı öğrenci aynı zamanda kalitenin de güvencesidir. İçine kapalı ve kerameti kendinden menkul bir eğitim ve araştırma çerçevesi ilkel kalmaya ve zamanı 1skalamaya mahkûmdur. Yabancı öğrenci ve araştırmacıların tüm bunların yansıra kültürel alışveriş imkânı oluşturmaları önemlilik arz eden bir diğer noktadır. (Savaşan, 2015). 
Gelişmiş Batı Avrupa ülkelerinin de ABD'ye göçü vermekte olduğu düşünüldüğünde beyin göçünden mustarip olan tek ülkenin Türkiye olmadığı söylenebilir. Türkiye bir taraftan beyin göçünü tersine çevirmek, dışarıda bulunan kendi beyinlerini geri kazanmak için uğraşırken diğer taraftan gelişmekte olan ülkelerden genç beyinler kazanabilir. Özellikle aynı kültür havzasında yer alan ülkeler arasındaki bu alışverişin kazananı topyekûn kültür havzası olacaktır (Savaşan, 2015).

\section{Uluslararası Öğrenci Hareketliği ve Türkiye}

Uluslararası öğrenci hareketliliğinin önemli bir seviyeye ulaştığı günümüzde gelişmiş ülkeler başta olmak üzere pek çok ülke bu öğrenci hareketliliğinden pay alma çabasına girmiştir. OECD istatistiklerine göre 1975 yılında 800 bin civarında olan uluslararası öğrenci sayısı, 2000-2012 yılları arasında yüzde 115 artış göstererek 2,1 milyondan 4,5 milyona çıkmıştır. Bu rakamın 2020 yılında 8 milyona çıkması beklenmektedir. (KB, 2014: 10).

Grafik 1: Uluslararası Öğrenci Sayılarının Yıllara Göre Değişimi (1975-2012) (Milyon Kişi)

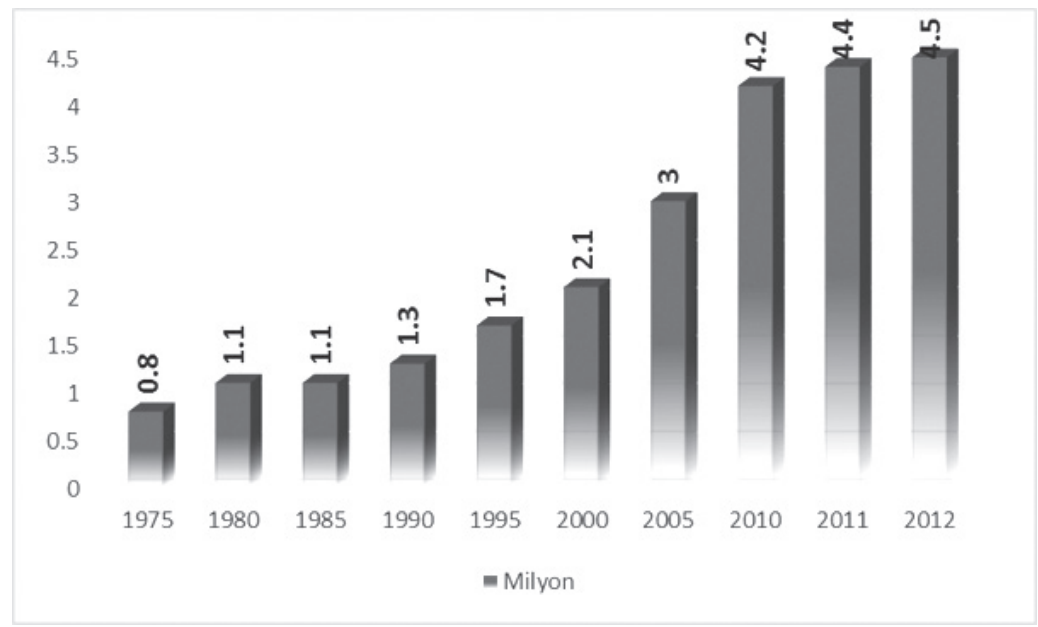

Kaynak: OECD, 2014:344

Uluslararası öğrenciler tarafından tercih edilen ülkelere bakıldığında Avrupa ve Kuzey Amerika uluslararası öğrenciler tarafından en çok tercih edilen bölgelerdir. Son y1llarda ise Latin Amerika ve Kara- 
yipler, Okyanusya ve Asya en hızlı gelişen bölgeler olmuştur. Ülkede konuşulan dil ise bu tercih nedenini etkileyen bir diğer unsurdur. $\mathrm{Bu}$ bağlamda ingilizce konuşulan ülkeler özellikle dillerinin kendilerine sağladığ1 avantajdan dolayı en çok öğrenci çeken ülkeler konumunda$\operatorname{dir}(\mathrm{KB}, 2014: 10)$.

2014 yılı OECD istatistiklerine göre uluslararası öğrencilerin \%126's1 eğitim için ABD'yi tercih etmiştir. ABD'yi \%15 ile İngiltere, $\% 11$ ile Fransa, \%10 ile Almanya ve \%8 ile Avustralya takip etmektedir. Türkiye ise uluslararası öğrencilerin \%1'ine ev sahipliği yapmaktadır. Uluslararası öğrencilerin ülkelere yapmış oldukları katkılar dikkate alındığında bu oranın artırılması gerekliliği belirtilmelidir.

Grafik 2: OECD ülkelerindeki Yabancı ve Uluslararası Öğrencilerin Eğitim Gördükleri Ülkelere Göre Yüzde Dağılımı (2014)

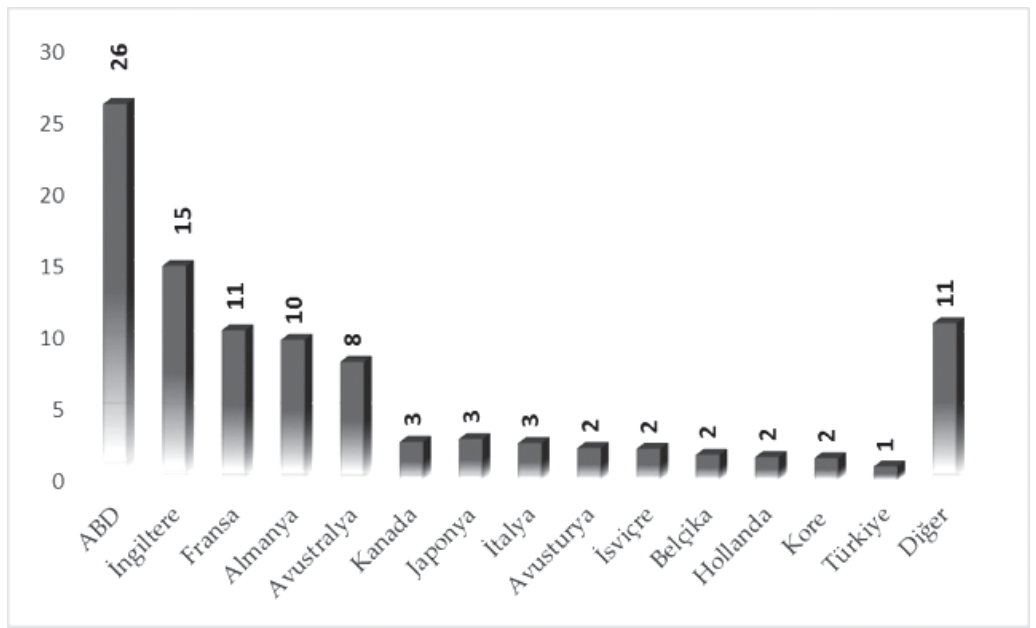

Kaynak: OECD, 2016: 331

Türkiye'deki uluslararası öğrenci sayısının yıllar itibarıyla, 2000-2005 arası hariç, genel olarak artış gösterdiği görülmektedir. Özellikle 2013-2015 yılları arasındaki yaklaşık \%50 oranındaki artış dikkat çekmektedir. 2015 y1lı verilerine göre Türkiye'de 87.903 uluslararası öğrenci eğitim görmektedir. 
Grafik 3: Türkiye'de Uluslararası Öğrenci Sayısındaki Gelişim

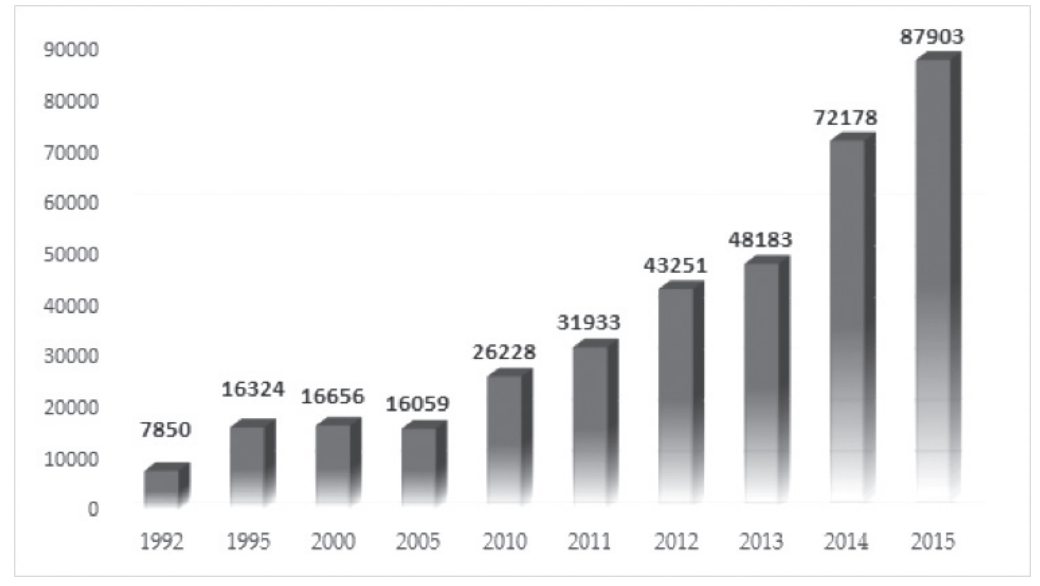

Kaynak: YÖK istatistikleri kullanılarak tarafımızdan hazırlanmıştır.

\section{Uluslararası Öğrencilerin Sosyo-Ekonomik Problemleri Üzeri- ne Literatür Özeti}

Uluslararası öğrenciler ile ilgili literatürde yapılmış birçok çalışma bulunmaktadır. Çalışmaların çoğu üniversite öğrencileri ile ilgili olsa da ortaöğretim düzeyinde yapılmış çalışmalar da bulunmaktadır. Örneğin, Göver ve Yavuzer (2015), ortaöğretim düzeyinde yaptıkları çalışmalarında Uluslararası Mustafa Germirli Anadolu İmam Hatip Lisesinde öğrenim gören 181 yabancı öğrenciye 57 soruluk anket uygulayarak yabancı uyruklu öğrencilerin Kayseri, Türkiye ve İslam algısını tespit etmeyi amaçlamışlardır. Çalışma sonucunda öğrencilerin Kayseri ve Türkiye hakkında büyük oranda olumlu algılara sahip oldukları bulgusu elde edilmiştir. Bir başka çalışmada Öner vd. (2011), ortaöğretim düzeyinde gerçekleştirdikleri araştırmalarında 2010-2011 yılında Kayseri'de lise son sınıfta okuyan yabancı uyruklu öğrencilerin yükseköğretime geçtiklerinde yaşadıkları problemleri tespit etmek için Kayseri'de orta öğretim kurumlarında okuyan 93 yabancı uyruklu öğrenciyle yüz yüze görüşme yapmış ve anket uygulamışlardır. Yazarlar araştırma sonucunda öğrencilerin en önemli üç probleminin sırasıyla "üst öğrenime geçememe korkusu”, "ekonomik sorunlar" ve "uyum sağlayamama" olduğunu belirlemişlerdir. 
Uluslararası öğrencilerin sorunları ile ilgili Türkçe literatürde ilk yapılan çalışmalardan birinde Can (1996), Ankara'daki beş üniversitede öğrenim gören 227 yabancı uyruklu öğrenci ile yapılan anket sonuçlarına göre öğrencilerin ilk yıl yoğun olmak üzere barınma sorunu yaşadıklarını, öğrencilerin Türk toplumuyla kültürel işbirliği ve etkileşimlerini gerçekleştirecek örgütsel ortamı bulamadıklarını, Türkiye'de yaşanan enflasyon, sağlık ve trafik sorunlarının yabancı öğrencileri de etkilediğini, öğrencilerin yiyecek masraflarının en önemli sorunlarından biri olduğunu, öğrencilere verilen burs miktarlarının çok düşük olduğunu belirtmiştir.

Güçlü (1996) ise, Pittsburgh Üniversitesi'nde lisansüstü eğitim yapan yabancı öğrencilerin uyum problemleri ve bunları çözebilmek için geliştirdikleri stratejiler ve başvurdukları yardım kaynaklarını incelediği çalışmasında Michigan Yabancı Öğrenci Problem Envanteri yöntemini kullanmış ve katılımcılara açık uçlu sorular yöneltmiştir. Çalışma sonucunda öğrencilerin algıladıkları problemlerin başında "İngilizce" ve "mali yardım” konularının yer aldığı, kız öğrencilerin, sağlık hizmetleri ve akademik kayıtlar alanlarında erkek öğrencilere nazaran daha fazla güçlüklerle karşılaştıkları, İngilizce yeterlik puanı yüksek olan öğrencilerin, düşük olanlardan daha az problemi olduğu, yabancı öğrencilerin uyum problemlerini çözmek için "vatan hasreti ve yalnızlık duygularını gidermek için, ülkelerine sık sık mektup yazmak, telefon etmek ve yakın arkadaşlıklar kurmak; İngilizcelerini geliştirmek için, Amerikalılarla konuşmak; mali destek sağlamak için üniversite dışında çalışmak ve arkadaşlarından ödünç para almak" gibi stratejiler geliştirdikleri ve yabancı öğrencilerin uyum problemlerini çözerken en büyük desteği ailelerinden aldıkları bulguları elde edilmiştir (Güçlü, 1996:101).

Çağlar (1999), Türk üniversitelerinde öğrenim gören Türk Cumhuriyetleri ve akraba topluluklar vatandaşı öğrencilerin karşılaştıkları sorunları belirlemeyi amaçladığı çalışmasında Hacettepe, ODTÜ, Atatürk ve Cumhuriyet Üniversitelerinden 210 öğrenci ile anket uygulamış ve öğrencilerin kendi içinde bir alt kültür oluşturdukları, Türkiye'deki kurumların öğrencilerin sorunlarına karşı duyarsız kaldıkları, öğrencilerin kendi ülkelerine gidiş ve dönüşlerinde bilet fiyatlarının pahalıl1ğ veya ulaşım araçlarında yer bulamama gibi ulaşıma dair sorunları 
olduğu, öğrencilerin genellikle KYK'da barındıkları ancak personelin tutum ve davranışlarından memnun olmadıkları, öğrencilerin aldıkları burs miktarının düşük olduğu sonuçlarını elde etmiştir.

Köylü (2001), Ondokuz Mayıs Üniversitesi İlahiyat Fakültesi'nde öğrenim gören 39 yabancı uyruklu öğrenciye uyguladığ 1 anket sonucunda öğrencilerin büyük bir kısmının Türkiye'ye ilk geldiklerinde dil, bürokrasi, uyum ve ekonomik problemlerle karşılaştıkları, Türkiye hakkında iyi bir imaja sahip olmadıkları, arkadaşları ile olan ilişkilerinden memnun oldukları, fakülte ve hocalar ile ilgili bazı problemleri oldukları, aldıkları derslerin faydasız ve yetersiz olduğunu düşündükleri, eğitimin pasif olduğundan şikayet ettikleri bulgularını elde etmiştir.

Otrar vd. (2002), Türk ve akraba topluluklarından öğrenim görmek için Türkiye'ye gelen öğrencilerin stres kaynakları, stresle başa çıkma tarzlarını ve bunların ruh sağlıkları üzerindeki etkilerini inceledikleri çalışmalarında 232 öğrenci ile görüşmüşlerdir. Araştırma sonucunda en çok karşılaşılan sorun ve en fazla stres yaratan faktörler olarak ekonomik problemler ve gelecek kaygısının olduğu vurgulanmaktadır. Erkeklerin problem odaklı başa çıkma tarzlarını daha fazla kullandığı, bayanlar ve yüksek stres yaşadığını ifade edenlerin daha fazla psikopatolojik semptom gösterdiği sonuçlarına ulaşılmıştır.

Toker vd. (2003), Uludağ Üniversitesi'nde öğrenim gören, Orta Asya Türk Cumhuriyetleri ile Yunanistan ve Bulgaristan'dan gelen 301 Türk asıllı öğrenci ile anket uygulanarak gerçekleştirdikleri çalışmaları sonucunda öğrencilerin derslerinin dışında kalan boş zamanlarını spor yaparak, kütüphaneye giderek, kitap okuyarak, az da olsa sinema ve tiyatroya giderek değerlendirdikleri tespit edilmiştir.

Bayraktaroğlu ve Mustafayeva (2010), Sakarya Üniversitesi'nde eğitim gören yabancı öğrencilerle yaptıkları ankete dayalı çalışmalar1 sonucunda yabanc1 uyruklu öğrencilerin memnuniyet düzeylerinin yüksek olduğu ve öğrencilerin Türkiye'de eğitim gördükleri için mutlu oldukları sonucuna ulaşmışlardır. Ayrıca araştırmada yer verilen açık uçlu sonuçlara verilen cevaplar yabancı uyruklu öğrencilerin Türk öğrencilerle kolay iletişim kurmalarının sebebinin kültürel ve dini açıdan benzer değerlerin paylaşılması olduğunu, Türk halkının misafirperver- 
liği, yardımseverliği, Türk topluluklarına duyulan özlemin öğrencilerin dikkatini çektiğini, öğrencilerin Türkiye'deki eğitim sistemini rüşvete imkân tanımamasından dolayı beğendiğini ancak eğitim sisteminden memnun olmayanların ise her şeyin ezbere dayanmasından şikâyetçi olduğunu ve bazı hocaların objektif davranmadıklarını düşündüklerini göstermektedir (Bayraktaroğlu ve Mustafayeva, 2010:290).

Çöllü ve Öztürk (2010), Türk Cumhuriyetleri, Türk ve Akraba Topluluklarından Türkiye’ye Yüksek öğrenim görmek amacıyla gelen öğrencilerin uyum ve iletişim sorunların belirlemek amacıyla Konya Selçuk Üniversitesi'nde öğrenim gören 100 öğrenci ile anket uygulamışlar ve öğrenci burslarının yetersiz olduğu, öğrencilerin ülkelerine ve ailelerine duydukları özlemin uyum sorunlarına yol açtığı, öğrencilerin uyum sorunlarının temelinde Türkiye Türkçesini yeterli konuşamamalarının yattığı sonuçlarına ulaşmışlardır.

Kesten vd. (2010), Türkiye'deki bir üniversitenin eğitim fakültesinde öğrenim gören yabancı uyruklu öğrencilerin eğitime ve dile ilişkin sorunlarını belirlemeyi amaçladıkları çalışmalarında 15 öğrenci ile yarı yapılandırılmış görüşme tekniği ile görüşme yapmışlar ve sonuçları nitel veri analizi yönetimini kullanarak değerlendirmişlerdir. Çalışma sonucunda katılımcıların Türkçeye yeterince hâkim olamayışlarının, okuduğunu anlama becerisini de olumsuz etkilediği, az sayidaki yabanc1 uyruklu öğrencinin yazma konusunda sorun yaşadığı, yabancı uyruklu öğrencilerin Türkiye'ye geldikleri ilk günlerde genel olarak kendini ifade etmede sıkıntı yaşadıkları, yabancı uyruklu öğrencilerin en az sorun yaşadıkları alanın dinleme becerisi olduğu, yabancı uyruklu öğrencilerin tamamının Türkiye'deki yükseköğretimin kalitesine yönelik olumlu görüş belirttiği, yabancı uyruklu öğrencilerin, öğrenim gördükleri üniversitedeki öğretim elemanlarının kendilerine ilişkin tutum ve davranışlarıyla ilgili bazı olumsuz görüşler bildirmekle beraber genel olarak olumlu görüş bildirdiği, yabancı uyruklu öğrencilerin derslere ilişkin yaşadıkları sorunların büyük ölçüde Türkçelerinin yetersiz olmasından kaynaklandığı sonuçlarına ulaşılmıştır (Kesten vd., 2010:65-66).

Kıroğlu vd. (2010), Türkiye'de eğitim fakültesinde öğrenim gören yabancı uyruklu öğrencilerin sosyo-kültürel ve ekonomik anlamda yaşadıkları sorunları belirlemeyi amaçladıkları araştırmalarında 
7 farklı ülkeden 15 yabancı uyruklu öğrenci ile yarı yapılandırılmış görüşme yöntemi sonucunda veriler elde etmişlerdir. Nitel veri analiz tekniklerinden betimsel analiz yaklaşımı kullanılarak elde edilen sonuçlara göre "yabancı uyruklu öğrencilerin kendi kültürleriyle Türk kültürünün benzerlik göstermesi nedeniyle Türkiye'de önyargı ya da dışlanma ile karşılaşmadıkları, yabancı uyruklu öğrencilerin ekonomik kaynaklarının sadece aileleri olduğu ve aileleri tarafından gönderilen paranın yetersiz kaldığı ve yabancı uyruklu öğrencilerin tamamına yakınının ev özlemi çektikleri ve ailelerini, arkadaşlarını ve memleketlerini özledikleri” tespit edilmiştir (Kıroğlu vd., 2010:26).

Gülnar (2011), araştırmasında kültürleşme ve medya kullanımı ilişkisini Selçuk Üniversitesi’nin 288 yabancı uyruklu öğrencileri arasında araştırmıştır. Çalışma sonucunda "kültürleşme tutumlarından bütünleşme tutumuna katılımcıların \%84.7'sinin sahip olduğu, katılımcıların ev sahibi medyayı etnik medyadan anlamlı olarak daha sık kullandıkları ve ayrışma tutumu ve etnik medya kullanımının anlamlı ve pozitif ilişkili olduğu" bulguları elde edilmiştir (Gülnar, 2011:52).

Traş ve Güngör (2011), 12 öğrenci ile yarı yapılandırılmış görüşme yapmış ve "öğrencilerin öğrenim gördükleri sırada herhangi bir sorun yaşamadıkları, çevrelerinden yeterli düzeyde sosyal destek alg1ladıkları ve kendilerini üniversitede öğrenim gören diğer öğrencilerin bir parçası olarak gördükleri ve sosyal bağlılık duygularının yüksek olduğu" sonuçlarına ulaşmışlardır.

Yiğit (2012), Selçuklu ve Konya üniversitelerine ait farklı fakültelerde öğrenim gören 196 yabancı uyruklu öğrenci ile anket uygulamış ve "yabancı uyruklu öğrencilerin temel psikolojik ihtiyaç puanlarında babanın eğitim düzeyine göre anlamlı düzeyde bir farklılaşma görülmezken, sadece özerklik psikolojik temel ihtiyaçları bakımından anne eğitim düzeylerine göre anlamlı fark olduğu" sonucuna ulaşmıştır. Yazar ayrıca yabancı uyruklu öğrencilerin "temel psikolojik ihtiyaçlarında yaşa göre anlamlı düzeyde farklılık gösterdiği, temel psikolojik ihtiyaçlarından ilişki ihtiyaçlarında kaçıncı sınıfta okuduklarına göre bir farklılaşma görülmediği, özerklik ve yeterlik temel psikolojik ihtiyaçlarında okudukları sınıflar bakımından farklılaşma görüldüğü ve yabancı uyruklu öğrencilerin temel psikolojik ihtiyaçlarında cinsiyet 
ayrımında anlamlı bir farklılık bulunmadığı" bulgularını elde etmiştir (Yiğit, 2012:317).

Gökalp (2012), 19 Mayıs Üniversitesi Samsun Eğitim Fakültesi'nde öğrenim gören Türk ve yabancı uyruklu öğrencilerin öğretim programlarına yönelik bakış açılarının öğrencilerin okudukları bölüm ile yaş, cinsiyet, medeni durum ve milliyet değişkenlerine göre farklılaşıp farklılaşmadığını incelediği araştırmada 53 Türk ve 53 yabancı uyruklu öğrenci ile anket yapmıştır. Elde edilen bulgulara göre, öğrencilerin öğretim programlarına bakış açılarında kız öğrencilerin lehine, evli öğrenciler lehine ve yabancı öğrenciler lehine anlamlı fark olduğu belirlenmiştir (Gökalp, 2012:139).

Çetin vd. (2012), Türkiye'de öğrenim gören yabancı uyruklu öğrencilerin turizm algılarını ve Türkiye'nin doğal ve kültürel turizm değerlerine ilişkin görüşlerini ortaya koymak amacıyla Gazi Üniversitesi Türkçe Öğretim Merkezi’nde (TÖMER) 2009-2010 eğitim öğretim yılında öğrenim gören 142 yabancı öğrenci ile tarama modeline dayalı bir araştırma yapmışlardır. Analizler sonucunda yabancı uyruklu öğrencilerin algı puanlarının cinsiyet, aile gelir durumu ve mezun olunan lise türü değişkenine göre anlamlı bir fark göstermediği tespit edilmiştir (Çetin vd., 2012:180).

Paksoy vd. (2012)'nin Kilis, Gaziantep ve Diyarbakır illerinde YÖS kapsamında eğitim gören 32 yabancı uyruklu öğrenci ile anket uyguladıkları çalışmalarında elde edilen bulgular kapsamında yabancı uyruklu öğrencilerin çoğunlukla erkek ve ailelerinin gelir düzeylerinin düşük düzeyde olduğu, öğrencilerin kendi ülkelerine döndüklerinde Türkiye'de eğitim görmeyi çevrelerindeki akranlarına tavsiye edeceklerini belirttiği, yaşadıkları olumsuzluklara rağmen Türkiye'deki eğitimden memnun kaldıkları, yakın çevresinde Türkiye'de eğitim görmeyen öğrencilerin daha başarılı oldukları ve Türkçeyi kendi ülkelerinde veya Türkiye'de öğrenmeleri arasında anlamlı bir farklılık bulunmadığı sonuçlarına ulaşılmıştır.

Beltekin ve Radmard (2013), Ankara Üniversitesi'nde öğrenim gören lisansüstü öğrencilerin üniversitenin akademik iklimine, akademik süreçlere, fiziksel ortama ve üniversitenin akademik niteliğine ilişkin görüşlerini saptamak amacıyla tarama modelini esas alan araştır- 
malarında "uygun örnekleme yöntemi" ile seçilen 119 öğrenci ile anket yapmışlardır. Çalışma sonucunda katılımcıların, öğretim elemanlarına yönelik "ilgi”, "yardım" ve "iletişim" ile "yeterli materyal kullanma, "etkili öğretim yöntemlerini kullanma", "adil ve tarafsı değerlendirme" konularında olumsuz yargılara sahip oldukları; üniversiteyi "kütüphane" ve "bilgisayar, fotokopi, internet, vb. destek hizmetleri say1 ve hizmetin sürekliliği” açısından yetersiz buldukları, "mesleki gelişim" ve "eğitimin niteliğì" konularında da olumsuz algı içerisinde oldukları sonuçlarına ulaşılmıştır (Beltekin ve Radmard, 2013:250).

Güleç ve İnce (2013), Türkçe öğrenmekte olan yabancı öğrencilerin sosyal ve kültürel anlamda öğrendikleri dile ilişkin yaşadıkları sorunları ortaya koymayı amaçladıkları çalışmalarında Sakarya Üniversitesi TÖMER'de öğrenim görmekte olan 13 farklı ülkeye mensup 29 öğrenci ile yapılandırılmış görüşme yapmışlardır. Çalışma sonuçlar1 öğrencilerin kıyafet konusunda büyük sorun yaşamadıklarını ancak yemek ve eğlence gibi konularda orta düzeyde bir problem yaşamakta olduklarını göstermektedir.

Tok ve Yıgın (2013), nitel araştırma desenlerinden durum çalışması olarak ele aldıkları çalışmalarında 57 yabancı uyruklu öğrenci ile yarı yapılandırılmış görüşmeler gerçekleştirmişlerdir. Çalışma sonucunda öğrencilerin Türkçeyi öğrenmede, ekonomi, eğitim, turizm, siyasi, evlenme gibi araçsal motivasyona; tarihi, akrabalık ve dini bağlar gibi bütünleştirici motivasyona sahip oldukları belirlenmiştir.

Biçer vd. (2014), Atatürk Üniversitesi DİLMER'de 2012-2013 eğitim-öğretim yılında Türkçe öğrenen B1 düzeyindeki beş yabancı öğrenci ile görüsserek yaptıkları nitel veri analizine dayalı araştırmaları sonucunda yabancı öğrencilerin başlıca sorunlarının telaffuz, alfabe, yazma, okutmanların hızlı konuşmaları ve hayat pahalılığı olduğu bulgularını elde etmişlerdir.

Babadağ vd. (2014), yabancı öğrencilerin sağlı alanında karş1laştıkları sorunları araştırmak amaciyla 2012- 2013 eğitim-öğretim y1lında Eskişehir Sağlık Yüksekokulu'nda öğrenim gören 7 farklı ülkeden 9 yabancı uyruklu öğrenci ile odak grup görüşmesine dayalı yaptıkları araştırmaları sonucunda öğrencilerin sağlı sorunları ile ilgili tıbbi yardım alırken zorlandıkları konuların iletişim zorlukları, kendi ülkelerine 
göre sağlık çalışanlarından daha az danışmanlık hizmeti alabilmeleri, sağlık sigortası düzenlenene kadar geçen sürede sağlık giderlerini kendileri karşılamak zorunda kalmaları olduğunu tespit etmişlerdir.

Şahin ve Demirtaş (2014), genel tarama modeline dayalı betimsel yöntem kullandıkları araştırmalarında 2012-2013 öğretim yılında İnönü Üniversitesi'nde öğrenim gören 96 gönüllü yabancı uyruklu öğrenci ile görüşmüşlerdir. Çalışma sonucunda genel olarak yabancı uyruklu öğrencilerin akademik başarısının çok düşük olduğu, öğrencilerin önde gelen sorunlarının daha çok ekonomik olup okul harçları, yemek kartı ve yemek, ulaşım, dil ve barınma gibi konularda yoğunlaştığ 1 tespit edilmiştir.

Alyılmaz vd. (2015) Atatürk Üniversitesi’nde öğrenim gören Kırgız öğrencilerin Türkçeye ve Türkiye'ye ilişkin görüşlerini ortaya koymak amacıyla $15 \mathrm{~K}$ ırgız öğrencinin görüşüne başvurdukları nitel araştırma modeline dayalı çalışmaları sonucunda Kırgız öğrencilerin Türkiye'ye karşı olumlu görüşler içerisinde oldukları, Türkçeyi kolay öğrenilebilir bir dil olarak gördükleri, Türk toplumunun kendilerine sıcak ve iyi davrandığı, öğrencilerin yaşadığı sorunların başında ise ekonomik sorunların yer aldığı sonuçlarını elde etmişlerdir.

Özkan ve Acar Güvendir (2015), Trakya ve Kırklareli Üniversitelerinden 38 uluslararası öğrenci ile gerçekleştirdikleri içerik analizi ve betimsel analize dayalı çalışma sonucunda uluslararası öğrencilerin genel anlamda üniversite yaşamlarından, arkadaş ve öğretim elemanlarından memnun oldukları, okudukları üniversitenin akademik beklentilerini karşıladığı ancak barınma ve ulaşım için herhangi bir yardım almadıkları bulgularını elde etmişlerdir.

Yılmaz (2015), Kazakistanlı öğrencilerin Türkiye Türkçesi öğrenirken yaşadığı sıkıntıları tespit etmek amacıyla tarama modeliyle yaptığı çalışmasında Kazakistan'da Süleyman Demirel Üniversitesi, Abay Üniversitesi, El-Farabi Üniversitesi, Merkez Orta Asya Üniversitesi ve Ablay Han Üniversitesi'nde okuyan 180 öğrenciden dinleme, okuma, konuşma ve yazma alanlarında yaşadıkları sıkıntıları yazmalarını istemiştir. Analiz sonucunda öğrencilerin ayrı ayrı her bir beceri alanında pek çok sıkıntı yaşadıkları ve bu sıkıntıların başında kelime hazinesinin yetersiz olması ve uygulamada yaşanan eksikliklerin geldiği tespit edilmiştir (Yılmaz, 2015:257). 
Musaoğlu (2016) İstanbulda biz özel üniversitede okuyan öğrencilerle yapmış olduğu mülakat sonuçlarına göre öğrencilerin yaşadıkları en büyük problemin Türkçe bilmemek olduğu, öğrencilerin sıkıntı yaşadıklarında bu sıkıntılarını en çok kendi ülkelerinden olan arkadaşları veya aileleri ile çözmeye çalıştıkları ve yeni gelecek öğrencilere verecekleri ilk tavisyenin Türkçe öğrenerek Türkiye'ye gelmek olduğunu ortaya koymuştur. Yazar ayrıca çalışmasında

Kumcağız vd. (2016), Ondokuz Mayıs Üniversitesi'nde eğitim gören yabancı uyruklu öğrencilerin sınıf düzeylerine göre yaşadıkları sorunların belirlemek amacıyla 112 yabancı ögrenci ile anket yapmışlardır. Araştırma sonucunda, yabancı uyruklu öğrencilerin sınıf düzeylerine göre Uyum Sorunları Ölçeği’nin dil sorunları, sosyo-kültürel sorunlar, oryantasyon sorunları ve kişisel sorunları alt boyutlarından elde edilen puanlarda istatistiksel olarak anlamlı bir farklılık görüldügü ancak mali sorunlar boyutundan elde edilen puanda anlamlı bir farklılık görülmediği bulgusu elde edilmiştir. Ayrıca 1 .sınıf ve 2 sınıf öğrencilerinin dili algılamakta zorlandıkları ve sorun yaşadıkları, 3. ve 4. sınıf öğrencilerinin dil becerilerinin zaman içinde daha yüksek düzeyde olduğu, sosyokültürel sorunların sınıf düzeyi yükseldikçe azalmasının nedeni olarak öğrencilerin üst sınıflara yükseldikçe sosyal etkinliklere katılımlarında yabancı dil yeterliliklerinin zaman içinde artmasının etkili olduğu hususları çalışmanın diğer sonuçlarıdır (Kumcağız vd., 2016:37).

Coşkunserçe ve Bedir Erişti (2017), uluslararası öğrencilerin Türk kültürüne ve çevreye uyum sürecinde kullanılabilecek bir çevrimiçi sistemden içerik beklentilerinin belirlenmesi, bu çevrimiçi sistemin tasarlanması ve hazırlanan çevrimiçi sistemin etkililiğinin uluslararası öğrencilerin görüşlerine göre geliştirilmesi olmak üzere üç aşamadan oluşan çalışmalarında Anadolu Üniversitesi Grafik Tasarımı Bölümü'nde lisans eğitimine devam eden dört uluslararası öğrenci ile görüşmüşlerdir. Çalışma sonucunda çevrimiçi sistemi kullanan uluslararası öğrencilerin içerik beklentilerinin tamamen karşılandığı tespit edilmiştir.

Ayrıca yabancı literatürde de uluslararası yabancı öğrencilerin sorunları ile ilgili yapılmış araştırmalar bulunmaktadır. Hellsten ve Prescott (2004), Macquarie Üniversitesi'nde 48 yabancı öğrenci ile gerçekleştirdikleri mülakatlar sonucunda artan yabancı öğrenci sayı- 
sının kalite ve uzmanlık sağlama açısından kurumlara yeterince yansımadığı sonucuna ulaşmışlardır.

Lee ve Rice (2007), Amerika' da öğrenim gören 15 ülkeden 24 yabancı öğrenci ile yaptıkları mülakatlar sonucunda uluslararası öğrencilerin karşılaştı̆̆ sorunların hepsinin olmasa da çoğunun ev sahibi toplumdaki yetersizliklerden kaynaklandığı sonucuna ulaşmışlardır.

Arambewela ve Hall (2009), Çin, Endonezya, Hindistan ve Tayland'dan gelip Avustralya'da öğrenim gören 573 yabancı öğrenci ile mail yoluyla yaptıkları ankete dayalı çalışmaları sonucunda elde edilen bulguları MANOVA ve ANOVA yöntemi ile analiz etmişler ve eğitim ve eğitim dışı hizmet kalitesi faktörlerinden memnuniyet düzeyinin öğrencilerin uyruğuna göre değiştiğini ve öğrenci memnuniyeti üzerinde etkisi olduğunu belirlemişlerdir.

Jenkins ve Galloway (2009) ise Tayvan'da öğrenim gören Çinli öğrencilerin uyum sorunlarını inceledikleri çalışmalarında Tayvan'daki 15 üniversitedeki 1174 uluslararası öğrenci ve 189 öğretim görevlisi ve personelinden alınan yanıtlar doğrultusunda uluslararası öğrencilerin yaşadıkları kültürel uyum sorunlarının nispeten önemsiz olduğu, öğretim üyelerinin ve personelin bu sorunları sürekli olarak abarttığını ve en önemlisi, İngilizce dilindeki sorunların hem öğrenci hem de öğretim üyeleri ve personel yanıtlarındaki değişimi daha fazla açıkladığı bulgularını elde etmişlerdir.

Evans ve Stevenson (2011) İngiltere'de hemşirelik alanında doktora yapan 9 farklı ülkeden 17 yabancı öğrenci ile mülakat yapmışlar ve öğrencilerin yeni bir ülke kültürüne uyum sağlamada, danışmanları ile uyum noktasında ve ikinci bir dil öğreniminde sorunları olduğu sonucuna varmışlardır.

\section{Uluslararası Lisans ve Lisansüstü Öğrencilerin Sosyo-Ekono- mik Problemleri: Sakarya Üniversitesi Örneği}

\subsection{Araştırmanın Amacı}

Bu çalışmada, Sakarya Üniversitesi'nde öğrenim gören uluslararası öğrencilerin sosyo-ekonomik problemlerinin neler olduğu arkadaşlık, sağlik, kültür, ekonomik, psikolojik, akademik, sosyal problemler başlıkları altında tespit edilmesi amaçlanmaktadır. 


\subsection{Araştırmanın Yöntemi}

Uluslararası lisans ve lisansüstü öğrencilerin sosyo-ekonomik problemlerinin tespitine yönelik yapılan bu çalışmada sosyal bilimlerde sıklıkla kullanılan anket yönteminden ve yarı yapılandırılmış mülakat tekniğinden yararlanılmıştır.

Aynı anket formunda Türkçe ve İngilizce olarak iki dilde hazırlanılan ankette araştırılmak istenen konunun amacını en iyi yansıtacak sorulara yer verilmiştir. Anket formunda genellikle 5'li Likert ölçeğe göre hazırlanmış sorular yer almaktadır. Ayrıca ankette katılımcıların demografik özelliklerini ölçmeye yönelik sorular da yer almaktadır.

Yarı yapılandırılmış mülakat tekniğinde ise öğrencilere anketteki ana konularla ilgili yaşadıkları ve karşılaştıkları problemlerin neler olduğu sorulmuş ve öğrencilerden gelen cevaplar anket cevapları ile birleştirilerek yorumlanmıştır.

Muhtemel hataları düzeltebilme ve anketten beklenen amacın gerçekleştirilmesi amaciyla her iki yöntem için pilot bir uygulama yapılmış, ilgili uzmanlarla görüşülmüş ve daha sonra anket Sakarya Üniversitesi'nde lisans ve lisansüstü eğitimine devam eden öğrencilere uygulanmıştır. Anketlerde elde edilen veriler SPSS programı kullanılarak analiz edilmiştir.

\subsection{Araştırmanın Ana Kütlesi ve Örnek Kitlesi}

Sakarya Üniversitesi'nde 2015 yılı verilerine göre 2052 adet uluslararas1 öğrenci eğitim görmektedir. Bu öğrencilerin 110 tanesi ön lisans, 1579 tanesi lisans, 119 tanesi doktora ve 298 tanesi ise yüksek lisans eğitimi alan öğrencidir.

Çalışmanın ana kütlesi Sakarya Üniversitesi'nde eğitim gören uluslararası lisans ve lisansüstü öğrencilerdir. Kaynakların kısıtlı olması nedeniyle ana kütlenin tamamına ulaşmak mümkün olmadığ1 için ana kütleyi temsil edecek öğrenciler arasından olasılık hesabına dayanmayan örnekleme tekniklerinden «kolayda örnekleme» yöntemi ile örnek kitle oluşturulmuştur. Ana kütlenin tamamına ulaşmanın kısitlı zaman ve yüksek maliyet nedeniyle mümkün olmadığı durumlarda deneklerin araştırmacı tarafindan seçildiği bir yöntem olan kolayda örnekleme sosyal bilimlerde sıkça kullanılmaktadır. Örnek 
kitleye uygulanan anketlerin 50 tanesi mail ortamında uygulanmış diğerleri ise yüz yüze anket tekniği ile uygulanmıştır. Toplamda 250 öğrenciye anket uygulanmış, 25 öğrenci ile yarı yapılandırılmış mülakat yapılmıştır.

\subsection{Uluslararası Öğrencilerin Karşılaştıkları Problemler: Anket ve Mülakat Sonuçları}

Bu kısımda Sakarya Üniversitesi'nde lisans ve lisansüstü eğitim gören öğrencilere yönelik yapılan anket ve mülakat sonuçlarının değerlendirilmesine yer verilmiştir.

\subsubsection{Demografik Göstergeler}

Aşağıdaki tablodan da görüldüğü gibi katılımcıların \%30.7'si 20 yaş ve altı, \%43.7'si 21-25 yaş aras1, \%16,3'ü 26-30 yaş arası, \%2,8'i 31-40 yaş arası, \%0,5'i 41 yaş ve üzeri iken $\% 6,0$ 'sı yaşını belirtmemiştir. Katılımcıların \%72'si erkek, \%28'i bayandır. Katılımcıların öğrenim durumları ise \%69,3 lisans, \%30,7'si lisansüstü şeklindedir. Lisans seviyesinde en çok öğrenci \%22,2'lik oranla Mühendislik Fakültesi'nden; lisansüstü seviyede ise en çok katılım \%20.8 ile Sosyal Bilimler Enstitüsü’nden gerçekleşmiştir.

Tablo 1: Lisans Ve Lisansüstü Öğrencilerin Demografik Özellikleri

\begin{tabular}{|l|l|c|}
\hline & & Yüzde (\%) \\
\hline \multirow{4}{*}{ Yaş } & 20 ve altı yaş & 30,7 \\
\cline { 2 - 3 } & $21-25$ yaş & 43,7 \\
\cline { 2 - 3 } & $26-30$ yaş & 16,3 \\
\cline { 2 - 3 } & $31-40$ yaş & 2,8 \\
\cline { 2 - 3 } & 41 ve üzeri yaş & 0,5 \\
\cline { 2 - 3 } & Belirtmeyen & 6,0 \\
\cline { 2 - 3 } Cinsiyet & Toplam & 100,0 \\
\hline & Bay & 72 \\
\cline { 2 - 3 } & Bayan & 28 \\
\cline { 2 - 3 } & Toplam & 100,0 \\
\hline
\end{tabular}




\begin{tabular}{|c|c|c|}
\hline \multirow{3}{*}{ Öğrenim } & Lisans & 69,3 \\
\hline & Lisansüstü & 30,7 \\
\hline & Toplam & 100,0 \\
\hline \multirow{20}{*}{ Fakülte/Enstitü } & Lisans & \\
\hline & Siyasal Bilgiler Fakültesi & 18.9 \\
\hline & İşletme Fakültesi & 10.8 \\
\hline & Hukuk Fakültesi & .5 \\
\hline & Tip Fakültesi & 1.4 \\
\hline & Mühendislik Fakültesi & 22.2 \\
\hline & Eğitim Fakültesi & 0.9 \\
\hline & Teknoloji Fakültesi & 3.8 \\
\hline & Fen Edebiyat Fakültesi & 6.1 \\
\hline & BESYO & .5 \\
\hline & Sağlık YO & 0.9 \\
\hline & Diğer & 2.8 \\
\hline & Lisansüstü & \\
\hline & Sosyal Bilimler Enstitüsü & 20.8 \\
\hline & Fen Bilimleri Enstitüsü & 6.6 \\
\hline & Eğitim Bilimleri Enstitüsü & .5 \\
\hline & Sağlık Bilimleri Enstitüsü & .5 \\
\hline & Ortadoğu Enstitüsü & .5 \\
\hline & Diğer & 2.4 \\
\hline & Toplam & 100,0 \\
\hline
\end{tabular}

Tablo 2: Öğrencilerin Geldikleri Ülkeler

\begin{tabular}{|l|c|l|c|l|c|}
\hline \multicolumn{1}{|c|}{ Ülke } & Yüzde & \multicolumn{1}{c|}{ Ülke } & Yüzde & \multicolumn{1}{c|}{ Ülke } & Yüzde \\
\hline Azerbaycan & 14.0 & Özbekistan & 1.4 & Çad & 0.5 \\
\hline Afganistan & 13.0 & Gana & 1.4 & Doğu Türkistan & 0.5 \\
\hline Suriye & 8.8 & Çin & 1.4 & Etiyopya & 0.5 \\
\hline Türkmenistan & 7.0 & Endonezya & 1.4 & Gine-Bissau & 0.5 \\
\hline Somali & 5.1 & Fas & 1.4 & Gürcistan & 0.5 \\
\hline Kosova & 3.3 & Abhazya & 0.9 & Haiti & 0.5 \\
\hline Arnavutluk & 2.3 & Cezayir & 0.9 & Irak & 0.5 \\
\hline
\end{tabular}




\begin{tabular}{|l|c|l|l|l|l|}
\hline Bosna Hersek & 2.3 & Kamerun & 0.9 & Kafkasya & 0.5 \\
\hline Kazakistan & 2.3 & Rusya & 0.9 & Kenya & 0.5 \\
\hline Pakistan & 2.3 & Sudan & 0.9 & Makedonya & 0.5 \\
\hline Kirgizistan & 2.3 & Tacikistan & 0.9 & Maritanya & 0.5 \\
\hline Filistin & 2.3 & Türkiye & 0.9 & Nijerya & 0.5 \\
\hline Almanya & 1.9 & Ürdün & 0.9 & Romanya & 0.5 \\
\hline Tayland & 1.9 & Zimbabve & 0.9 & Sirbistan & 0.5 \\
\hline Gine & 1.4 & Bangladeş & 0.5 & Togo & 0.5 \\
\hline Yemen & 1.4 & Bulgaristan & 0.5 & Tunus & 0.5 \\
\hline Yunanistan & 1.4 & Burundi & 0.5 & Uganda & 0.5 \\
\hline
\end{tabular}

Yukarıdaki tablodan da görüldüğü gibi katılımcıların \%14.0’ü Azerbaycan, \%13.0'ü Afganistan, \%8.8'i Suriye, \%7.0'si Türkmenistan, \%5.1'i Somali ve \%3.3'ü Kosova'dandır. Diğer ülkelerden olan kat1lımciların oranları \%3'ün altında seyretmektedir.

Tablo 3: Öğrencilerin Türkiye'de Bulundukları Süre, okudukları sınıf, öğrenim türleri

\begin{tabular}{|c|c|c|c|}
\hline \multicolumn{2}{|c|}{$\begin{array}{l}\text { Öğrencilerin Türkiye'de } \\
\text { Bulundukları Süre }\end{array}$} & \multicolumn{2}{|c|}{ Öğrencilerin Okuduğu Sınıf } \\
\hline Yil & Yüzde & Sinıf & Yüzde \\
\hline 2 y1l & 30.2 & 1.sinif & 25.7 \\
\hline $1 \mathrm{y} 11$ & 23.7 & $2 . \sin 1 f$ & 23.8 \\
\hline 3 yil & 18.6 & TÖMER & 12.1 \\
\hline 5 ay & 11.2 & Yüksek Lisans & 13.1 \\
\hline 4 y1l & 8.8 & $3 . \sin 1 f$ & 10.7 \\
\hline $5 \mathrm{y} 11$ & 4.7 & 4.sinif & 8.8 \\
\hline $6 \mathrm{y} 11$ & 0.9 & Doktora & 5.6 \\
\hline $10 \mathrm{y} 11$ & 0.5 & \multicolumn{2}{|c|}{ Öğrencilerin Öğrenim Türü } \\
\hline $15 \mathrm{y} 11$ & .5 & Öğrenim Türü & Yüzde \\
\hline $20 \mathrm{y} 11$ & .5 & 1. Öğretim & 81.4 \\
\hline 22 y1l & .5 & 2. Öğretim & 16.1 \\
\hline
\end{tabular}

Yukarıdaki tabloda da görüldüğü üzere ankete katılan öğrencilerin \%30.2'si iki yıldan beri, \%23.7'si bir yıldan beri, \%18.6'sı ise üç yıl- 
dan beri Türkiye'de bulunmaktadır. Katılımcılardan on yıl ve üzeri sürede Türkiye' de bulunanların oranı yaklaşı $\% 2$ ' dir.

Ankete katılan öğrencilerin \%49.5' ini birinci sınıf ve ikinci sınıf öğrencileri oluşturmaktadır. En az katılım ise \%5.6'lık oranla doktora öğrencileri tarafından gerçekleşmiştir.

Ankete katılan öğrencilerin \%81.4'ü birinci öğretim öğrencileri, \%16.1'i ikinci öğretim öğrencileri iken \%2.0'si ise karma eğitim öğrencileridir.

Tablo 4. Öğrencilerin Sağlık Sigortası ve Öğrencilerin Ülkelerine Gitme Siklığ1

\begin{tabular}{|l|c|l|c|}
\hline \multicolumn{2}{|c|}{ Öğrencilerin Să̆lık Sigortası } & Öğrencilerin Ülkelerine Gitme Sıklı̆̆ı \\
\hline \multicolumn{1}{|c|}{ Sigorta } & Yüzde & \multicolumn{1}{|c|}{ Süre } & Yüzde \\
\hline Yok & 26.8 & Diğer (Bir Yılın Üzerinde) & 45.9 \\
\hline $\begin{array}{l}\text { Var- Özel } \\
\text { Sigorta }\end{array}$ & 26.8 & Yılda Bir & 32.9 \\
\hline $\begin{array}{l}\text { Var- Genel } \\
\text { Sigorta }\end{array}$ & 46.3 & Altı Ayda Bir & 15.9 \\
\hline Toplam & 100,0 & Üç Ayda Bir & 4.8 \\
\hline & Ayda Bir & .5 \\
\hline
\end{tabular}

Tablondan da görüldüğü gibi ankete katılan öğrencilerin \%46.3'ü genel sigortadan, \%26.8'i özel sigortadan yararlanmakta iken \%26.8'i hiçbir sigortası bulunmamaktadır. Öğrencilerle yapılmış olan mülakatlarda özellikle kendi imkânları ile Türkiye'de eğitimine devam eden öğrenciler özel sağlık sigortasından faydalanırken problemler yaşadıklarını belirtmişlerdir.

Ankete katılan öğrencilerin \%32.9'u yılda bir kez, \%15.9'u altı ayda bir, \%4.8'i üç ayda bir ve \%0.5'i ayda bir kendi ülkelerine gitmektedirler. Katılımcıların yaklaşık yarısı (\%45.9) ülkelerine bir yı1dan uzun süreli aralıklarla gitmektedirler. Buradan da görüldüğü gibi öğrencilerin büyük çoğunluğu ülkelerine bir yıldan daha uzun sürelerde gidebilmektedir. 


\section{Grafik 4: Öğrencilerin İkamet Ettikleri Yer (\%)}

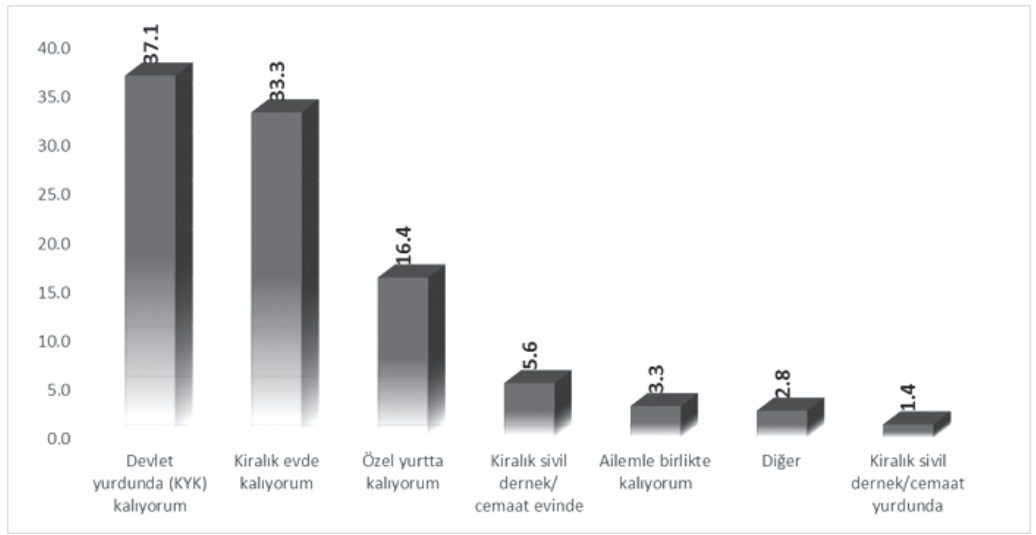

Grafikten de görüldüğü üzere katılımcıların \%37.1'i devlet yurtlarında, \%33.3'ü kiralık evlerde ve \%16.4'ü özel yurtlarda kalmaktadırlar. Ankete katılanların toplam \%13.1'lik kısmını ise ailesiyle birlikte kalan öğrenciler, kiralık sivil dernek/cemaat evinde kalan öğrenciler, kiralık sivil dernek/cemaat yurdunda kalan öğrenciler ve diğer bazı yerlerde kalan öğrenciler oluşturmaktadır.

Grafik 5: Öğrencilerin İkamet Masrafları (\%)

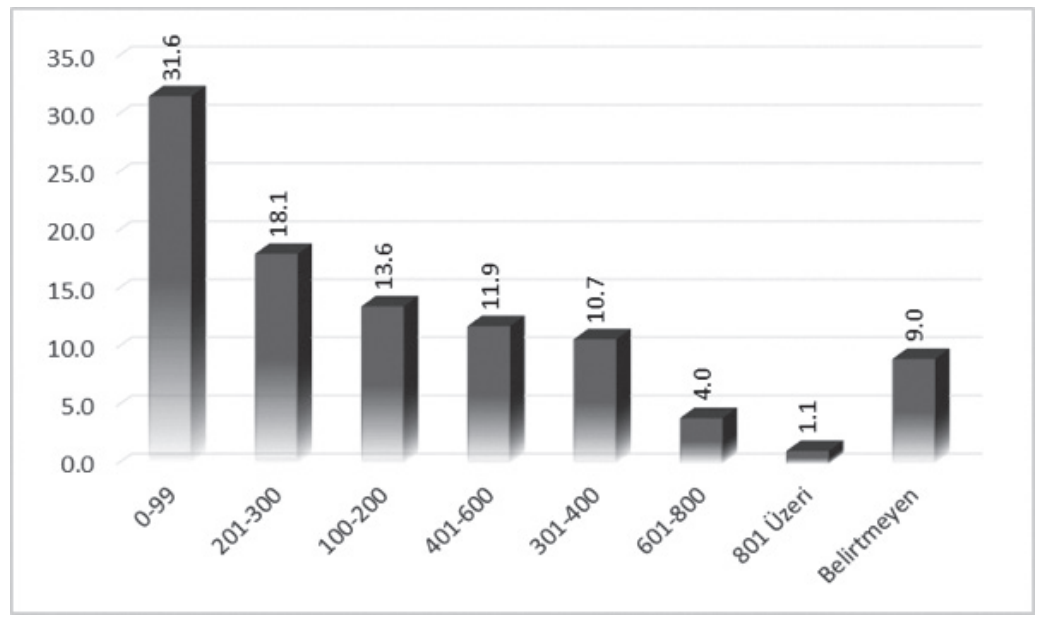

Katılımcılara kalmış oldukları yere ne kadar kira verdikleri sorulmuştur. Buradan da görüldüğü gibi katılımcıların \%31.6'sı 100 liranın al- 
tında kira ödemektedirler. Ankete katılan öğrencilerden kaldıkları yere 300 lira ve üzeri ücret ödeyenlerin oranı ise \%26.7'dir.

Grafik 6: Öğrencilerin Aylık Toplam Geliri

(Burs, Aile Yardımı ve Diğerleri) (\%)

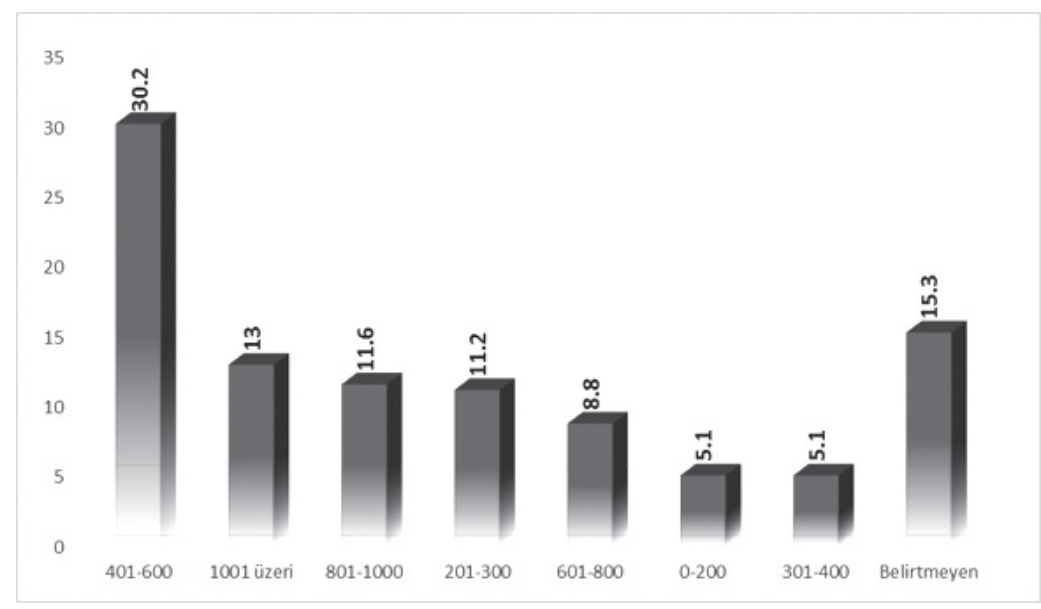

Ankete katılan öğrencilerin \%30.2'si 401-600 TL arasında gelire, \%13'ü 1001 ve üzeri TL gelire, \%11.6's1 801-1000 TL arasında gelire sahip olduğunu belirtmiş, \%15.3'ü ise gelirini belirtmemiştir.

Grafik 7: Türkiye'ye/Sakarya'ya

Gelmeden Önce Türkçe Biliyor Muydunuz? (\%)

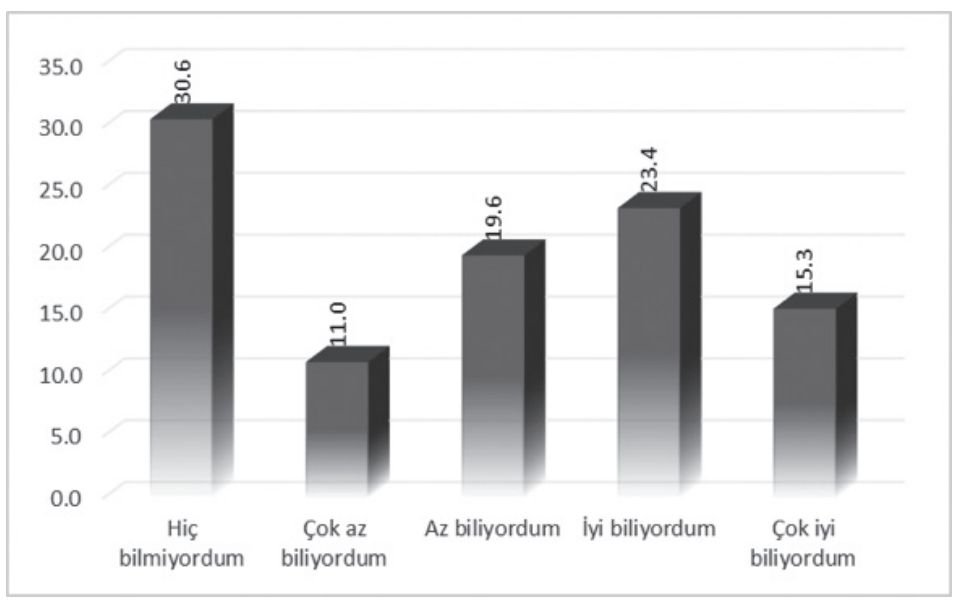


Katılımcıların \%38.7'si Türkiye'ye gelmeden önce Türkçeyi bildiklerini, \%30.6's1 ise hiç bilmediğini belirtmişlerdir.

\subsubsection{Eğitim İçin Türkiye'yi Tercih Nedeni}

Öğrencilere eğitim için Türkiye'yi neden tercih ettikleri sorulmuştur.

Grafik 8: Öğrencilerin Eğitim için Türkiye’yi Tercih Nedeni (\%) ${ }^{4}$

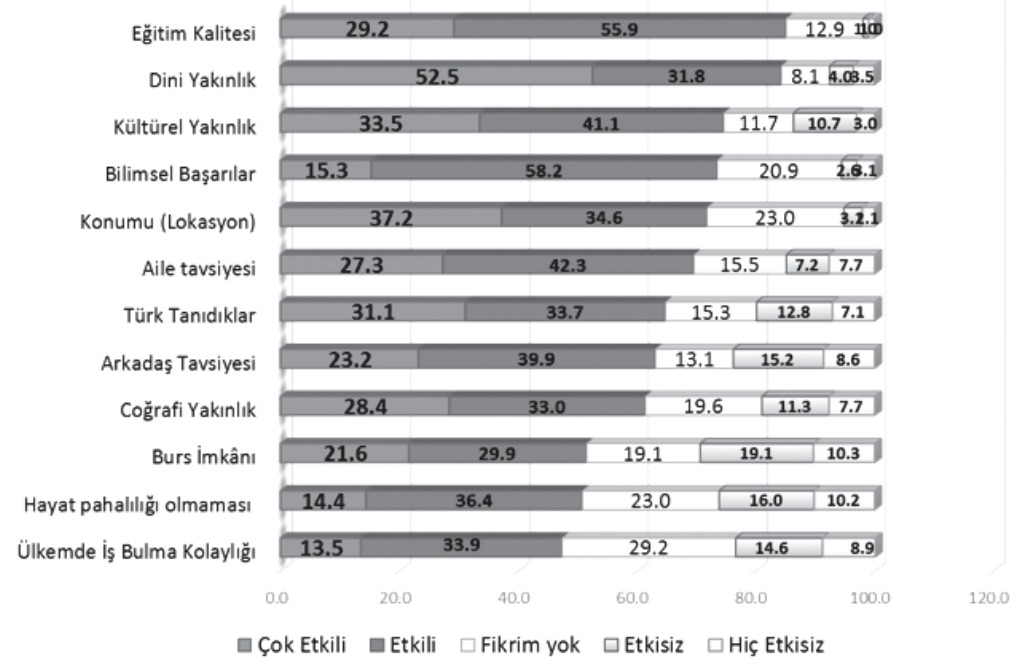

Yukarıdaki grafikten de görüldüğü gibi ankete katılan öğrenciler Türkiye'yi tercih nedeni olarak ileri sürülen en önemli nedenler; \%85.1 Eğitim kalitesi, \%84.3 Dini Yakınlık\%74.6 Kültürel Yakınlık, \%73.5 Bilimsel başarılar, \%71.8 Konum, \%69.6 Aile Tavsiyesi, \%64.8 Türk Tanıdıklar, \%63.1 Arkadaş Tavsiyesi, \%61.4 Coğrafi Yakınlık, \%51.5 Burs imkânı'dır.

\footnotetext{
4 İçsel tutarlılığın ölçümünde en yaygın kullanılan yöntem Cronbach Alpha olarak bilinen alfa katsayısıdır. Alfa değer olası olası tüm ikiye ayırma kombinasyonları sonucu ortaya çıkacak olan ikiye ayırma katsayılarının bir ortalamasını göstermektedir ve 0 ila 1 arası değerler almaktadır. Her ne kadar literatürde kabul edilebilir değer 0.7 olması belirtilse de bu değerin 0.5 'e kadar makul kabul edilebileceği öngörülmektedir (Altunışık ve diğ, 2010). Bu çalışmada iç tutarlılığın ölçümü bu katsayı kullanılarak yapılmıştır. Öğrencilerin eğitim için Türkiye'yi tercih nedeni ile ilgili sorulara ilişkin iç tutarlılığın araştırılması amacıyla yapılan Cronbach's Alpha test değeri 0.670'dir. Bu anlamda öğrencilere yöneltilen soruların iç tutarlılığa sahip olduğu belirtilebilir.
} 


\subsubsection{Uluslararası Lisans ve Lisansüstü Öğrencilerin Arkadaşlık Sorunlart}

Uluslararası öğrencilerin arkadaşlık sorunlarının tespiti için ankete katılan öğrencilere arkadaşlıkla ilgili verilen yargılara katılma dereceleri sorulmuştur.

Ankete katılan öğrencilere arkadaşlıkla ilgili verilen yargılara katılma dereceleri sorulmuştur. Öğrencilerin vermiş olduğu cevaplar ağırlık derecelerine göre aşağıda sunulmuştur. Öğrencilerin; \%69.1'i Türk arkadaşlarının kendilerine genellikle yardım ettiğini, \%68.6'sı Türk arkadaşlarının kendilerine karşı anlayışlı olduğunu, \%64.9'u Dil problemi yüzünden Türkler ile iletişim kurmakta zorlanmadığını, \%63.5'i Yabanc1 öğrencilerin diğer yabancı öğrencilere karşı tutumlarının iyi olduğunu, \%63.1'i Türk olmayan öğretim üyeleri ile ilişkilerinin iyi olduğunu, \%62.6'sı kendilerini Türk arkadaşlarının yanında rahat hissettiğini, \%59.5'i Türk arkadaşları ile iletişimde sorunlar yaşamadığını, \%48'i Türk öğretim üyeleri ile ilişkilerinin iyi olduğunu belirtmektedir.

Grafik 9: Uluslararası Lisans ve Lisansüstü Öğrencilerin Arkadaşlık ve İletişim Durumları $(\%)^{5}$

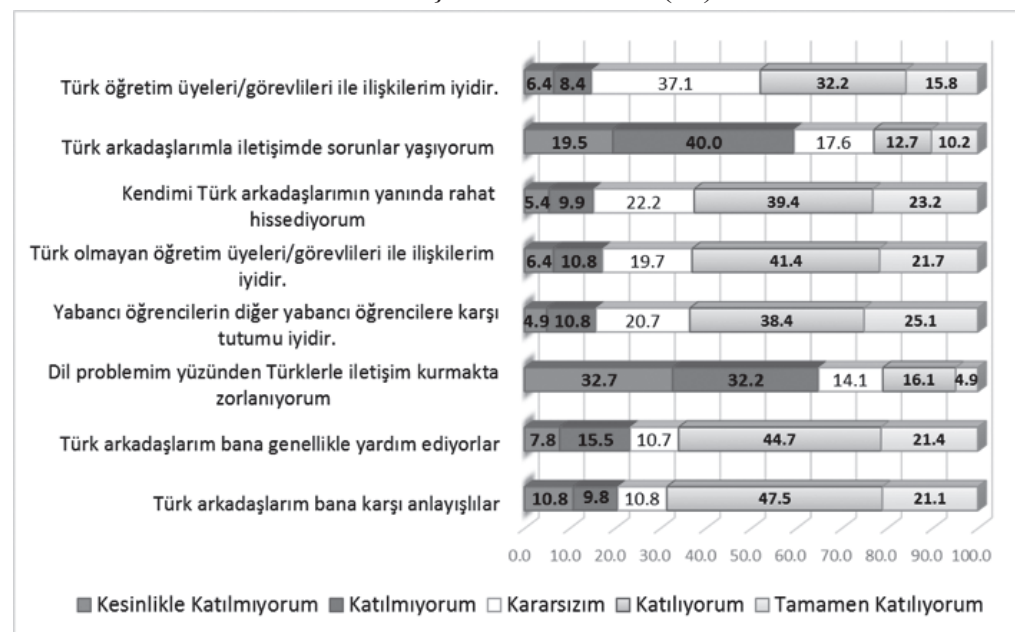

5 Öğrencilerin eğitim için arkadaşlık ve iletişim sorunları ile ilgili sorulara ilişkin iç tutarlılığın araştırılması amacıyla yapılan Cronbach's Alpha test değeri 0.668'dir. Bu anlamda öğrencilere yöneltilen soruların iç tutarlılığa sahip olduğu belirtilebilir. 
Ankete katılan öğrencilere arkadaşlıkla ilgili verilen yargılara katılma dereceleri sorulmuştur. Öğrencilerin vermiş olduğu cevaplar ağırlık derecelerine göre aşağıda sunulmuştur. Öğrencilerin; \%68.6'sı Türk arkadaşlarının kendilerine karşı anlayışlı olduğunu, \%66'sı Türk arkadaşlarının kendilerine genellikle yardım ettiğini, \%64.9'u Dil problemi yüzünden Türkler ile iletişim kurmakta zorlanmadığını, \%63.5'i Yabancı öğrencilerin diğer yabancı öğrencilere karşı tutumlarının iyi olduğunu, \%63.1'i Türk olmayan öğretim üyeleri ile ilişkilerinin iyi olduğunu, \%62.6'sı kendilerini Türk arkadaşlarının yanında rahat hissettiğini, \%59.5'i Türk arkadaşları ile iletişimde sorunlar yaşamadığını, \%48'i Türk öğretim üyeleri ile ilişkilerinin iyi olduğunu belirtmektedir.

\section{Mülakatlarda dikkat çeken noktalar;}

Yapılan mülakatlarda öne çıkan problemler aşağıdaki şekilde belirtilebilir;

- Türk Cumhuriyetlerinden gelen öğrenciler (Azerbaycan, Türkmenistan, Kırgızistan gibi) arkadaşlık konusunda sorun yaşamadıklarını, Türklerin kendilerine iyi davrandıklarını belirtmişlerdir. Ancak özellikler Afrika kökenli öğrenciler ten renklerinden dolayı sorunlar yaşadıklarını belirtmektedirler.

- Öğrencilerin hemen hemen tamamı Türk arkadaşlarının Türkçeleri dolayısıyla kendiler ile dalga geçtiğini bunun da konuşma motivasyonlarını düşürdüğünü konuşmaya korktuklarını ve çekindiklerini belirtmektedirler.

- Öğrenciler genelde zamanlarının büyük kısmını kendi memleketlileri veya diğer yabancı öğrencilerle geçirdiklerini söylemişlerdir.

- KYK'da yurtlarda beraber kaldıkları Türklerin de kendileri ile ilgili olumsuz düşüncelere sahip olduğunu belirten bayan ve erkek öğrenciler vardır. Bir öğrenci "Bazı arkadaşlara siz temiz değilsiniz dediler. Yurtta bizle değil başka arkadaşlarla kalmak istediler ve odadan ayrıldılar" demiştir. Bir bayan öğrenci ise "Odaya bir Türk öğrenci geldi biz iki yabancı odadaydık bizi görünce ağlamaya başladı" demiştir. 
- Yine özellikle Afrika kökenli öğrenciler kendilerine rahatsız edici sorular sorulduğunu belirtmektedir. Örnek olarak "Eviniz var mı?, Yemek yiyiyor musunuz?, Su içiyor musunuz?, İnsan eti yiyiyor musunuz? gibi sorular sorduğunu söylemiştir. Öğrencilerin ve halkın Afrikalı bir öğrenciyi gördüğünde bu öğrencinin acı çektiği ve yardıma muhtaç olduğunu düşündüğü gibi bir algıya sahip olmuşlardır.

- Türk öğrencilerin uluslararası öğrencileri burs aldıklarından dolayı kıskandığı, bizim vergimizi siz alıyorsunuz dendiği, bizim hakkımızı çiğneyip burada okuyorsunuz gibi tacizlere uğradıklarını söylemişlerdir. Bir bayan öğrenci "Bir gün kantinde oturuyordum bir kız geldi al bu makaleyi Türkçeye çevir dedi." demiştir.

\subsubsection{Uluslararası Lisans ve Lisansüstü Öğrencilerin Sağlık Sorunlart}

Ankete katılan öğrencilere sağlıkla ilgili verilen yargılara katılma dereceleri sorulmuştur. Öğrencilerin vermiş olduğu cevaplar ağırlık derecelerine göre aşağıda sunulmuştur. Öğrencilerin; \%40'^ sağlı hizmetlerinden faydalanırken sorun yaşamadığını, \%35.2'si sağlık sigortası ile ilgili sorun yaşamadığını, \%58.4'ü Türkiye'nin iklimine alıştığını, \%36.8'i sağlık hizmetlerine ulaşmakta zorlandıklarını, \%34.7'si sağlık sorunu olduğunda yeterli tedavi imkanı bulamadıklarını, \%32.5'i sunulan sağlık hizmetlerinin yeterli olmadığını, \%41'i yabancı öğrenciler için sağlık hizmetlerinin ucuz olmadığını belirtmektedir.

Burada özellikle öğrencilerin sağlık ile ilgili birçok konusunda genellikle fikir beyan etmemeleri dikkat çekmektedir. 
Grafik 10: Uluslararası Lisans ve Lisansüstü Öğrencilerin Sağlık Sorunları (\%)

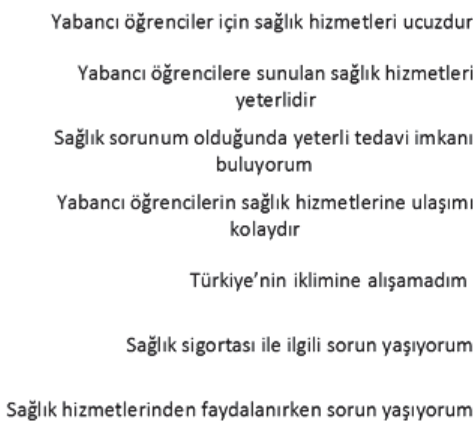

\begin{tabular}{|c|c|c|c|c|c|c|}
\hline 22.5 & 18.5 & \multicolumn{2}{|c|}{41.0} & & 14.5 & 3.5 \\
\hline 15.5 & 17.0 & \multicolumn{2}{|l|}{40.5} & \multicolumn{2}{|l|}{20.0} & 7.0 \\
\hline 17.1 & 17.6 & 31.2 & & 28.1 & & 6.0 \\
\hline 16.9 & 19.9 & 36.8 & & 17.9 & & 8.5 \\
\hline 23.3 & & 5.1 & 14.4 & 19.8 & & 7.4 \\
\hline 13.1 & 22.1 & 24.6 & & & 17.6 & \\
\hline 17.0 & 23.0 & 26.5 & & 20.0 & 13. & 1.5 \\
\hline
\end{tabular}

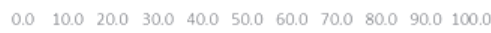

$\square$ Kesinlikle Katılmıyorum $\square$ Katılmıyorum $\square$ Kararsızım $\square$ Katılıyorum $\square$ Tamamen Katılıyorum

\section{Mülakatlarda dikkat çeken noktalar;}

- Özellikle kendi sigortasını yatıran öğrenciler sağlık sigortası ile ilgili sorunlar yaşadıklarını belirtmişlerdir.

- Ortadoğu kökenli öğrencileri de genelde Suriyeli sandıkları için doktorda olumsuzluklar yaşadıklarını belirtmektedirler.

- Öğrenciler genelde Türk yemeklerine alışamadıkları ve kendilerinin de yemek yapma imkânlarının olmaması dolayısıyla sağlıklı beslenemediklerini söylemektedirler.

\subsubsection{Uluslararası Lisans ve Lisansüstü Öğrencilerin Kültürel Sorunlart}

Ankete katılan öğrencilere kültürel konular ile ilgili verilen yargılara katılma dereceleri sorulmuştur. Öğrencilerin vermiş olduğu cevaplar ağıllık derecelerine göre aşağıda sunulmuştur. Öğrencilerin; \%52'si Türk yemeklerine alışamadım yargısına katılmadığını, \%42.8'i

6 Öğrencilerin eğitim için sağlık ile ilgili sorulara ilişkin iç tutarlılığın araştırılması amaciyla yapılan Cronbach's Alpha test değeri 0.602 'dir. Bu anlamda öğrencilere yöneltilen soruların iç tutarlılığa sahip olduğu belirtilebilir. 
Türkiye'de sağlıklı beslendiklerini, \%61.9'u Türk adet ve göreneklerini anlamakta zorlanmadığını, \%16'sı Türkiye'deki yaşam tarzına alışamadığını, \%52.7'si damak tadına uygun yemek bulmakta zorluk çekmediğini belirtmektedir.

Grafik 11: Uluslararası Lisans ve Lisansüstü Öğrencilerin Kültürel Sorunları (\%) ${ }^{7}$

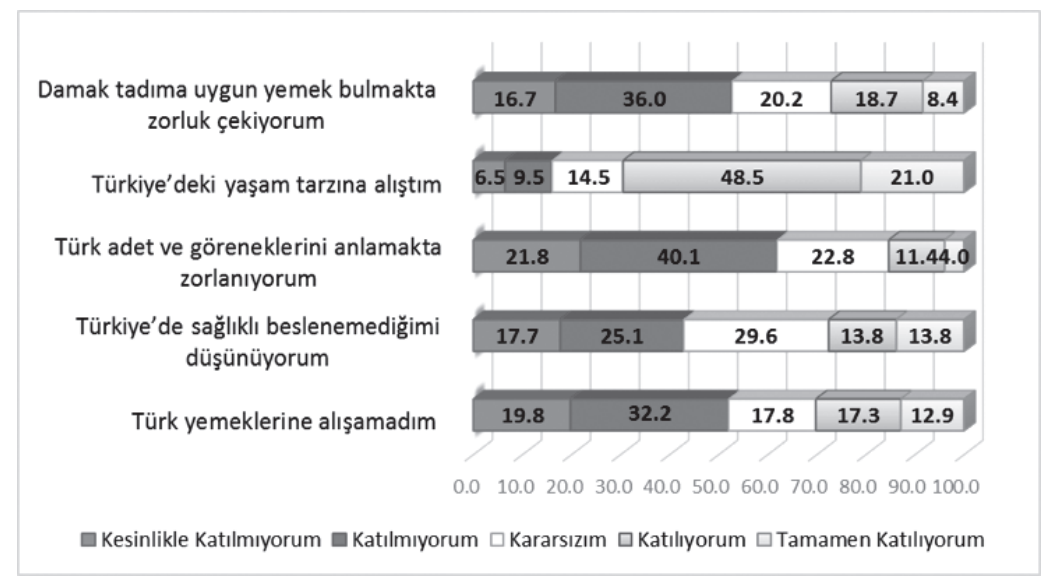

Yukarıdaki grafikten de görüldüğü gibi ankete katılan uluslararası lisans ve lisansüstü öğrencilerin kültürel sorunları arasında öne çıkan sorun \%30.2 (17.3+12.9)'lik oranla Türk yemeklerine alışamamaktır. Öğrencilerin \%69.5'lik kısmı ise Türkiye'deki yaşam tarzına alıştıklarını belirtmişlerdir.

\section{Mülakatlarda dikkat çeken noktalar;}

- Anketteki sonuca benzer bir şekilde mülakat yapılan öğrencilerin büyük çoğunluğu tam anlamıyla Türk yemeklerine alışamadıklarını belirtmişlerdir. Kendi yemeklerini yapmak istedikleri halde KYK'da bu tarz bir imkânlarının olmadıklarını söylemişlerdir.

7 Öğrencilerin kültür ile ilgili sorulara ilişkin iç tutarlılığın araştırılması amacıyla yapılan Cronbach's Alpha test değeri 0.654'dir. Bu anlamda öğrencilere yöneltilen soruların iç tutarlılığa sahip olduğu belirtilebilir. 
- Kendi kültürlerine uygun yemek yemek için ise varsa ev kiralamış arkadaşları, bu arkadaşlarının evlerinde yemek özlemlerini giderdikleri belirtilmiştir.

\subsubsection{Uluslararası Lisans ve Lisansüstü Öğrencilerin Ekonomik Sorunlart}

Ankete katılan öğrencilere ekonomik konular ile ilgili verilen yargılara katılma dereceleri sorulmuştur. Öğrencilerin vermiş olduğu cevaplar ağırlık derecelerine göre aşağıda sunulmuştur. Öğrencilerin; \%45,5'i ekonomik olarak zorluk yaşamadığını, \%42,1'i kalacak yer maliyetlerinin yüksek olduğu, \%46,2'si sağlık sigortası maliyetinin yüksek olduğunu belirtmektedir.

Grafik 12: Uluslararası Lisans ve Lisansüstü Öğrencilerin Ekonomik Sorunları (\%)

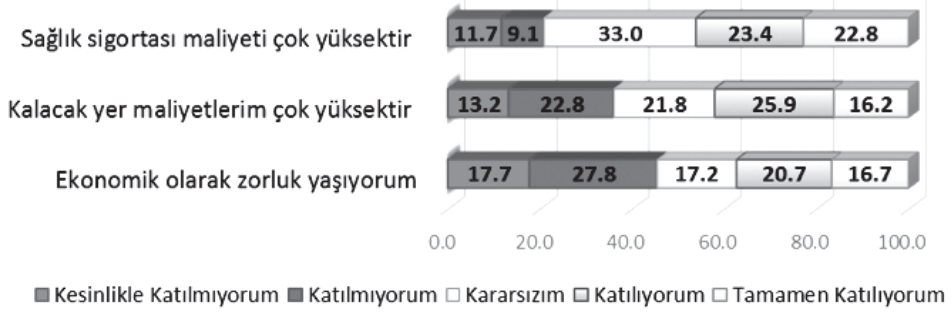

Yukarıdaki grafikten de görüldüğü gibi ankete katılan uluslararası lisans ve lisansüstü öğrencilerin ekonomik sorunları arasında birinci sıray $\% 57.5^{\prime}$ 'lik oranla Türkiye' deki yaşam maliyetlerinin yüksekliği alırken, öğrencilerin \%42.1'lik kısmı kalacak yer maliyetlerinin çok yüksek olduğunu belirtmiştir.

\section{Mülakatlarda dikkat çeken noktalar;}

- Özellikle kendi imkânları ile okumak isteyen öğrenciler ekonomik olarak zorluk çektiklerini belirtmişlerdir.

8 Öğrencilerin ekonomik konularla ile ilgili sorulara ilişkin iç tutarlılı̆̆ın araştırılması amacıyla yapılan Cronbach's Alpha test değeri 0.652 'dir. Bu anlamda öğrencilere yöneltilen soruların iç tutarlılığa sahip olduğu belirtilebilir. 
- Dışarıda yemek yemek istemeleri durumunda ekonomik olarak burslarının yetmediğini belirtmişlerdir.

- YTB burslusu öğrenciler yaz döneminde memleketlerine gitmedikleri zamanlarda dışarıda yemek yemek durumunda kaldıkları ve burslarının yetmediğini belirtmişlerdir.

\subsection{7. Öğrencilerin Psikolojik Sorunları}

Ankete katılan öğrencilere psikolojik konular ile ilgili verilen yargılara katılma dereceleri sorulmuştur. Öğrencilerin vermiş olduğu cevaplar ağırlık derecelerine göre aşağıda sunulmuştur. Öğrencilerin; \%56.9'u Türkiye'de kendini yalnız hissetmediğini, \%64.4'ü ailesini özlediğini, \%60.8'i ülkesindeki arkadaşlarını özlediğini, \%49.5'i memleketlerinden ayrı kalmanın kendilerini üzdüğünü, \%32'si Türkiye'deki insanların yabancı öğrencilere karşı önyargılı olmadığını, \%53.3'ü farklılıkları nedeniyle dışlandığını düşünmediğini, \%67'si çevremdekilerle rahat ilişki kuramıyorum yargısına katılmadıklarını belirtmektedir.

Grafik 13: Uluslararası Lisans ve Lisansüstü Öğrencilerin Psikolojik Sorunları (\%) ${ }^{9}$

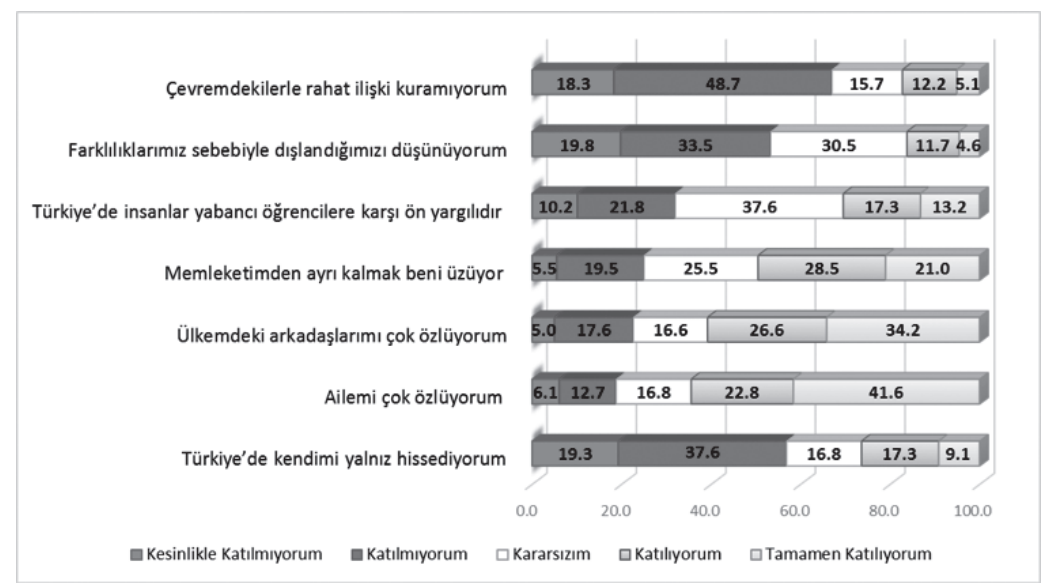

9 Öğrencilerin psikolojik sorunlarına ilişkin iç tutarlılığın araştırılması amacıyla yapılan Cronbach's Alpha test değeri 0.695 'tir. Bu anlamda öğrencilere yöneltilen soruların iç tutarlılığa sahip olduğu belirtilebilir. 
Yukarıdaki grafikten de görüldüğü gibi ankete katılan uluslararası lisans ve lisansüstü öğrencilerin psikolojik sorunları arasında ilk sırayı \%61.4 ile aile özlemi seçeneği almaktadır.

\section{Mülakatlarda dikkat çeken noktalar;}

- Öğrencilerin en çok belirttikleri sorun aile ve memleket özlemidir.

- Öğrenciler kendilerini bazen yalnız hissettiklerini ve gizli gizli ağladıklarını belirtmişlerdir.

- Afrika kökenli öğrenciler ise ten renklerinden dolayı hem öğrenci arkadaşları hem de halkın tavırlarını kendilerini rahatsız ettiğini söylemişlerdir.

\subsection{8. Öğrencilerin Akademik Sorunlart}

Grafikten de görüldüğü gibi ankete katılan uluslararası lisans ve lisansüstü öğrencilerin akademik sorunları arasında birinci sırada \%36.5 ile oranla dersleri anlamakta çekilen güçlük yer almaktadır.

Ankete katılan öğrencilere akademik konular ile ilgili verilen yargılara katılma dereceleri sorulmuştur. Öğrencilerin vermiş olduğu cevaplar ağırlık derecelerine göre aşağıda sunulmuştur. Öğrencilerin; $\% 44$ 'ü dersleri anlamakta zorlanmadığını, \%50.5'i ders hocasının konuşmasını takip edebildiğini, \%51.3'ü ders hocalarıyla rahat iletişim kurabildiğini, \%61.5'i üniversiteyle ilgili bir sorunla karşılaştığında yardım edecek kimseleri bulabildiğini, \%49.5'i aldıkları eğitimin akademik beklentilerini karşıladığını, \%63.5'i aldıkları eğitimin gelecek planlarına yardımcı olduğunu, $\% 45.8$ 'i aldıkları eğitim ile kendi ülkelerinde kolay bir şekilde iş bulabileceğini, \%69.7'si aldıkları eğitimden memnun olduklarını belirtmektedir. 
Grafik 14: Uluslararası Lisans ve Lisansüstü Öğrencilerin Akademik Sorunları (\%) $)^{10}$

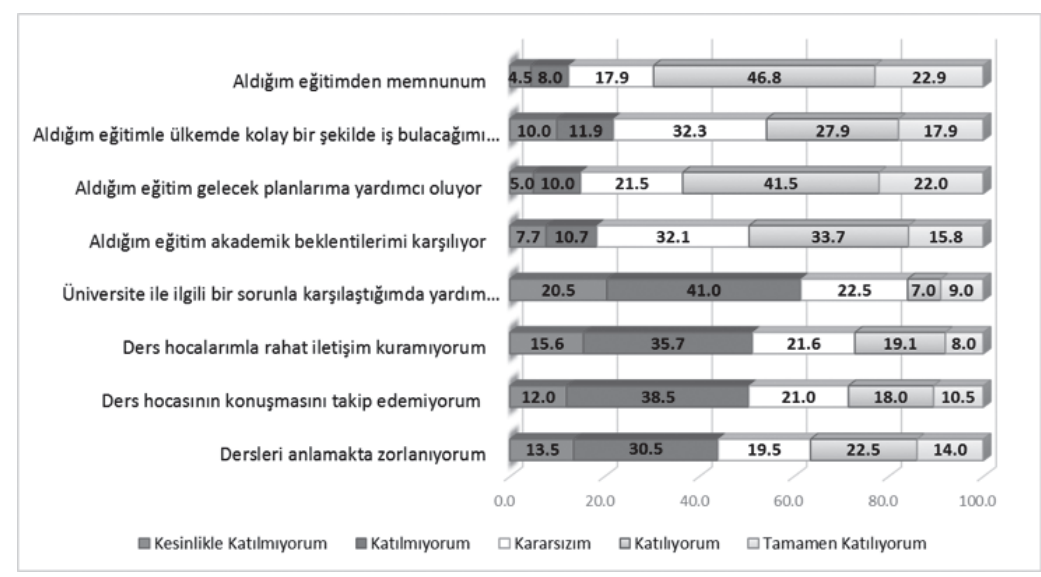

\section{Mülakatlarda dikkat çeken noktalar;}

- Akademik olarak en fazla öne çıkan sorun öğrencilerin özellikle sözel dersleri anlamakta zorlanmasıdır. Ayrıca öğrenciler yazılı sınavlarda da zorlandıklarını belirtmektedirler. Türk Cumhuriyetlerinden gelen öğrenciler ise bu sorunu daha az belirtmiştir.

- Öğrenciler sınavlarda İngilizce yazmak istedikleri halde buna izin verilmemesini de eleştirmektedirler.

\subsubsection{Uluslararası Lisans ve Lisansüstü Öğrencilerin Sosyal Sorunlart}

Ankete katılan öğrencilere genel anlamda Sakarya ve Türkiye algısı ile ilgili verilen yargılara katılma dereceleri sorulmuştur. Öğrencilerin vermiş olduğu cevaplar ağırlık derecelerine göre aşağıda sunulmuştur. Öğrencilerin; \%72.2'si Türkiye'de yaşamaktan mutlu olduğunu, \%66.4'ü Sakarya'da yaşamaktan mutlu olduğunu, \%41.8'i şehirdeki sosyal imkânların öğrenciler için yeterli olduğunu, \%35.6's1 şehirdeki kültürel imkânların yetersiz olduğunu belirtmektedir.

10 Öğrencilerin akademik sorunlarına ilişkin iç tutarlılığın araştırılması amacıyla yapılan Cronbach's Alpha test değeri 0.602'dir. 
Grafik 15: Genel Anlamda Sakarya ve Türkiye Algısı (\%) $)^{11}$

Şehirdeki kültürel imkânlar (sinema, tiyatro gibi) yetersizdir

Şehirdeki sosyal imkânlar öğrenciler için yeterlidir

Sakarya'da yaşamaktan mutluyum

Türkiye'de yaşamaktan mutluyum

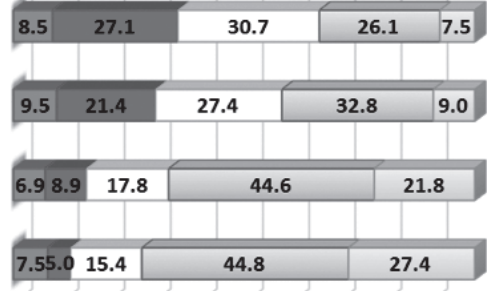

$0.0 \quad 10.020 .030 .040 .050 .060 .070 .080 .090 .0100 .0$

$\square$ Kesinlikle Katılmıyorum $\square$ Katılmıyorum $\square$ Kararsızım $\square$ Katılıyorum $\square$ Tamamen Katılıyorum

\section{Mülakatlarda dikkat çeken noktalar;}

- Mülakata karılan Öğrenciler Sakarya'da ve Türkiye'de yaşamaktan genel anlamda mutlu olduklarını belirtmektedirler.

Grafik 16: Şehirdeki Halkın ve Esnafın Yabancı Öğrencilere Karşı Tutum ve Davranışları $(\%)^{12}$
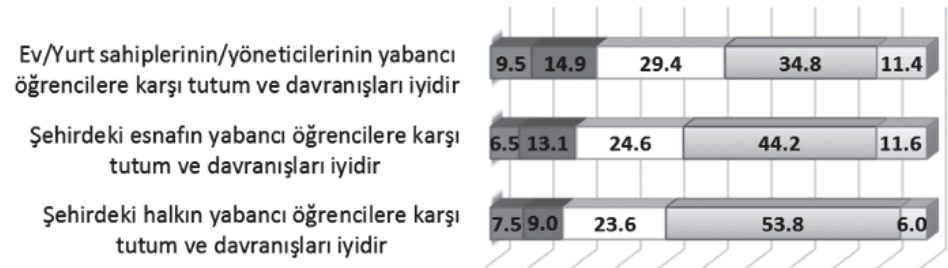

0.010 .020 .030 .040 .050 .060 .070 .080 .090 .0100 .0

$\square$ Kesinlikle Katılmıyorum $\square$ Katılmıyorum $\square$ Kararsızım $\square$ Katılıyorum $\square$ Tamamen Katılıyorum

Ankete katılan öğrencilere şehirdeki halkın ve esnafın yabancı öğrencilere karşı tutum ve davranışları ile ilgili verilen yargılara katılma dereceleri sorulmuştur. Öğrencilerin vermiş olduğu cevaplar ağırlık derece-

11 Öğrencilerin Sakarya ve Türkiye algısına ilişkin iç tutarlılığın araştırılması amacıyla yapılan Cronbach's Alpha test değeri 0.609'dür. Bu anlamda öğrencilere yöneltilen soruların iç tutarlılığa sahip olduğu belirtilebilir.

12 Şehirdeki halkın ve esnafin öğrencilere karşı tutumuna ilişkin iç tutarlılığın araştırılması amacıyla yapılan Cronbach's Alpha test değeri 0.683'dür. Bu anlamda öğrencilere yöneltilen soruların iç tutarlılığa sahip olduğu belirtilebilir. 
lerine göre aşağıda sunulmuştur. Öğrencilerin; \%59.8'i şehirdeki halkın yabancı öğrencilere karşı tutum ve davranışlarının iyi olduğunu, \%55.8'i şehirdeki esnafın yabancı öğrencilere karşı tutum ve davranışlarının iyi olduğunu, \%46.2'si ev/yurt sahiplerinin/yöneticilerinin yabancı öğrencilere karşı tutum ve davranışlarının iyi olduğunu belirtmektedir.

\section{Mülakatlarda dikkat çeken noktalar;}

- Öğrenciler tarafından bazı esnafların uluslararası öğrencilere mal satarken daha yüksek fiyat uyguladığı belirtilmektedir. Bir öğrenci örnek olarak Bir gün arkadaş taksiye bindi şöför 100 dolar istedi, bir aha hiç binmedi" demiştir.

Grafik 17: Uluslararası Lisans ve Lisansüstü Öğrencilerin Sosyal Sorunları

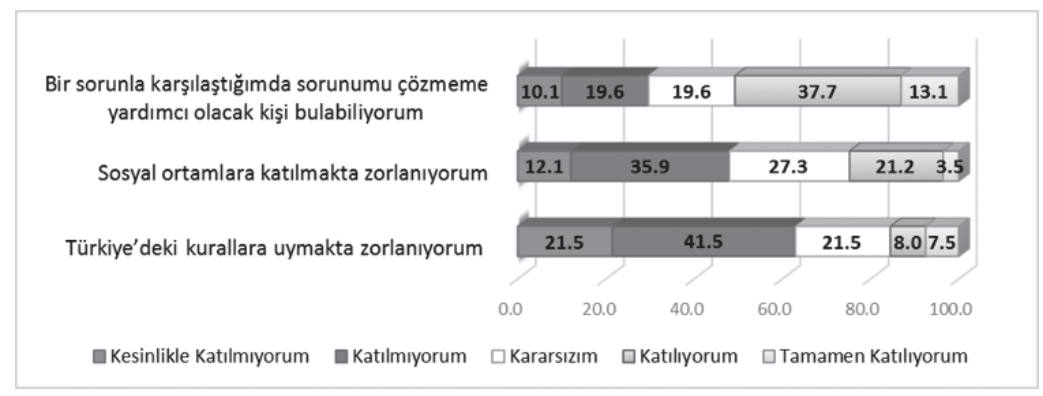

Ankete katılan öğrencilere uluslararası lisans ve lisansüstü ögrencilerin sosyal sorunları ile ilgili verilen yargılara katılma dereceleri sorulmuştur. Öğrencilerin vermiş olduğu cevaplar ağırlık derecelerine göre aşağıda sunulmuştur. Öğrencilerin; \%63'ü Türkiye'deki kurallara uymakta zorlanmadığını, \%48'i sosyal ortamlara katılmakta zorlanmad1ğını, \%50.8'i bir sorunla karşılaştığında sorununu çözmesine yardımcı olacak kişi bulabildiğini belirtmektedir.

\section{Mülakatlarda dikkat çeken noktalar;}

- Öğrenciler bir sorunla karşılaştıklarında genellikle kendi memleketlilerinden bir öğrencinin ya da diğer uluslararası öğrencilerin kendilerine yardım ettiğini belirtmektedirler.

- Özelikle YTB burslusu öğrenciler Sakarya'da bir temsilcinin olması gerektiğini belirtmektedirler. 
Grafik 18: Türkiye'deki Eğitiminizi Yarıda Bırakıp Ülkenize Dönmeyi Düşündünüz Mü? (\%)

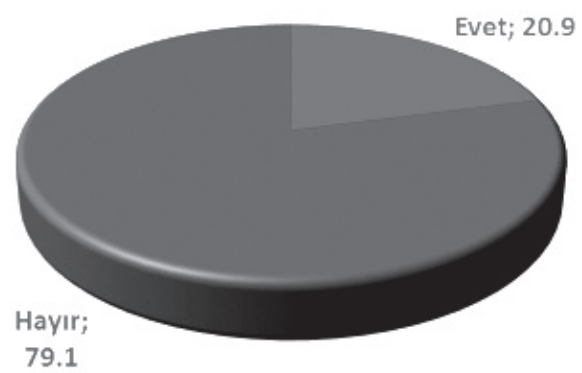

Yukarıdaki şekilden de görüldüğü gibi ankete katılan öğrencilerin \%20 .9'u Türkiye'deki eğitimini yarıda bırakıp ülkelerine dönmeyi düşünmesine karşın \%79.1'i böyle bir düşünceye sahip olmamıştır.

Ankete katılan öğrencilerden Türkiye'deki eğitiminizi yarıda bırakıp ülkenize dönmeyi düşündünüz mü sorusuna evet cevabı verenlerin nedenleri ağırlık derecelerine göre aşağıda sunulmuştur. Öğrencilerin; \%74'ü beklentilerinin karşılanmamasının etkili olduğunu, \%64.3'ü maddi sıkıntı yaşamanın etkili olduğunu, \%62.9'u memleket özleminin etkili olduğunu, \%53.9'u yeterli desteğin verilmemesinin etkili olduğunu, \%44'ü arkadaşlarıyla anlaşamamanın etkili olmadığını,

Grafik 19: Evet Diyenlerin Gerekçesi (\%)

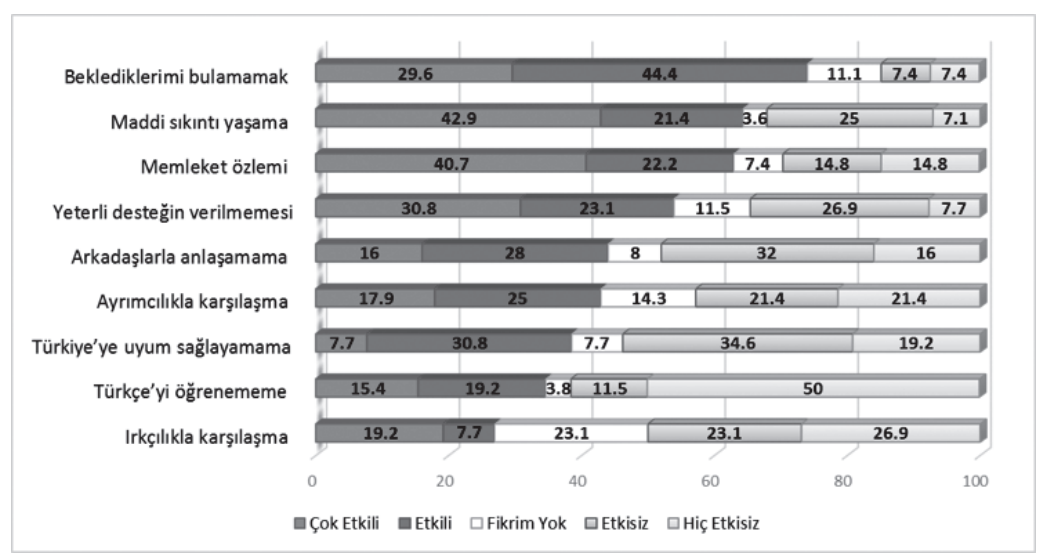


Yukarıdaki grafikten de görüldüğü gibi Türkiye'deki eğitimini yarıda bırakıp ülkelerine dönmeyi düşünenleri en çok etkileyen durum ilk iki neden olarak öğrencilerin beklediklerini bulamamaları ve maddi s1kıntı çekmeleri görülmektedir. En az etkileyen nedenler ise ırkçılıkla karşılaşmaları ve arkadaşları ile anlaşamamaları olarak görülmektedir.

\section{Öğrenciler ile yapılmış olan mülakatlarda ayrıca aşağıdaki husus- lar da dikkat çekmektedir.}

- Öğrenciler bir sorunla karşılaştıklarında Sakarya Yedi Renk Derne $\breve{g}^{13}{ }^{1}$ 'nin kendilerine yardımcı olduğunu belirtmektedirler.

- Öğrenciler herhangi bir sorun karşısında genelde kendi memleketlilerinden ya da uluslararası diğer öğrencilerden yardım aldıklarını belirtmektedirler.

- Öğrenciler kaldıkları yurtların (özellikle bayan yurdu) çok kalabalık olduğunu belirtmektedirler.

- Öğrenciler kendi damak tatlarına uygun yemek yapmak istediklerinde kaldıkları yurtta buna izin verilmediği belirtmektedirler.

- YTB burslusu öğrenciler YTB ile iletişim problemleri yaşadıklarını belirtmektedirler.

- Özellikle YTB burslusu öğrenciler yazın memleketlerine gidemedikleri ve Türkiye'de kadıkları zamanlarda yurtlarda çok fazla yer değiştirildiklerini (tadilat ve bakımlar dolayısıyla) ve yaz boyunca yurtlarda yemek çıkmamasından dolayı yemek maliyetlerinin arttığını ve burslarının yaz döneminde kendilerine yetmediğini belirtmektedirler.

13 edirenk, yurtdışından Sakarya'ya eğitim için gelen öğrencilere, eğitim ve rehberlik hizmeti vermek amacıyla kurulmuş uluslararası bir öğrenci derneğidir. Yedirenk Uluslararası Öğrenci Derneği ile ilgili ayrıntılı bilgi için bakınız; http://www.yedirenksakarya.com/ 
Grafik 20: Ülkenize Döndüğünüzde Çevrenizdekilere Türkiye'de Eğitim Görmelerini Tavsiye Eder Misiniz?(\%)

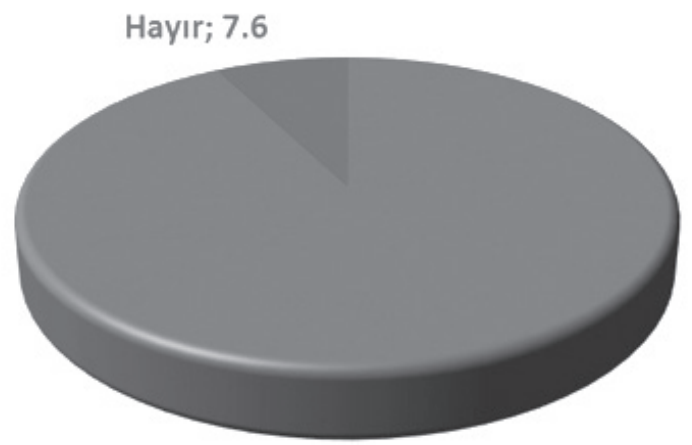

Evet; 92.4

Öğrencilerin \%92.4'ü ülkelerine döndüklerinde çevrelerindekilere Türkiye'de eğitim görmelerini tavsiye edeceklerini belirtmişlerdir.

\section{Sonuç ve Öneriler}

Bu kısımda öncelikle araştırma sonucunda elde edilen bulgular ortaya konulacak, daha sonra ise bu bulgulara dayanarak öneriler sunulacaktır.

\subsection{Sonuç}

Araştırma bulguları aşağıdaki gibi özetlenebilir.

\section{Türkiye'yi tercih nedeni;}

Ankete katılan öğrencilerin Türkiye'yi tercih nedeni olarak ileri sürülen en önemli nedenlerin başında eğitim kalitesi, dini yakınlık, kültürel yakınlık, aile tavsiyesi, bilimsel başarılar gelmektedir.

\section{Dil ve IIletişim sorunları;}

Ankete katılan öğrencilere dil problemi dolayısıyla iletişim kurmakta zorlanıp zorlanmadıkları sorulduğunda öğrenciler dil yüzünden iletişim kurmakta zorlanmadıklarını söylemişlerdir. Bu anlamda "Öğrencilerin dil ve iletişim ile ilgili sorunları vardır" hipotezi tam anlamıyla doğrulanamamaktadır. Ancak burada öğrencilerin dörtte birinin dil ve iletişim problemi yaşadıklarını da belirtmek gerekir. 


\section{Arkadaşlık sorunları;}

Ankete katılan öğrencilere arkadaşlıkla ilgili verilen yargılara katılma dereceleri sorulduğunda anket cevaplarında öğrencilerin arkadaşlıkla ilgili eğitim hayatlarını etkileyecek derecede ciddi sorunlarının olmadığı görülmüştür. Bu anlamda "Öğrencilerin arkadaşlıkla ile ilgili sorunları vardır" hipotezi tam anlamıyla doğrulanamamaktadır.

Ancak yapılan mülakatta öğrenciler farklı sorunlara değinmişlerdir. Bunların başında uluslararası öğrencilerin Türkçe konuşmalarındaki aksaklıkların Türk öğrenciler tarafından dalga konusu yapılması gelmektedir. Bu ise öğrencilerin Türkçe konuşmakta çekinmelerini beraberinde getirmekte ve öğrenciler Türkçelerini ilerletememektedirler. Bunun yansıra Afrika ülkelerinden gelen öğrencilerin ten renklerinden dolayı farklı problemlerle karşılaştıkları görülmüştür. Özellikle Türk öğrencilerin ve şehir halkın Afrika kökenli öğrencilere karşı tutumları öğrencileri rahatsız etmektedir. Yabancı öğrencilerin bir sorun olarak gerek yurtta gerekse sınıflarındaki Türk arkadaşlarının kendilerini kıskandıkları ve haklarını çaldıklarını düşündüklerini belirtmekledirler.

\section{Să̆lık sorunları;}

Ankete katılan öğrencilere sağlık ile ilgili verilen yargılara katılma dereceleri sorulduğunda anket cevaplarında öğrencilerin ciddi sorunlarının olmadığı görülmüştür. Öğrenciler genelde sağlık hizmetlerinden çok fazla yararlanmadıklarından sağlık konusunda genellikle fikir beyan etmemişlerdir. "Öğrencilerin sağlık ile ilgili sorunları vardır" hipotezi tam anlamıyla doğrulanamamaktadır.

Ancak yapılan mülakatta kendi kaynakları ile okuyan öğrencilerin sağlık sigortası konusunda sorunlarının olduğu görülmüştür.

\section{Kültürel sorunlar;}

Ankete katılan öğrencilere kültür ile ilgili verilen yargılara katılma dereceleri sorulduğunda anket cevaplarında öğrencilerin ciddi sorunlarının olmadığı görülmüştür. "Öğrencilerin kültür ile ilgili sorunları vardır" hipotezi tam anlamıyla doğrulanamamaktadır.

Ancak yapılan mülakatta Uluslararası öğrencilerin beslenme konusunda özelikle ilk yıllarda Türk yemeklerine alışamamaları dolayı- 
sıyla sorunlar yaşamaktadırlar. Özellikle YTB burslusu olan KYK'da kalan öğrenciler yurtlarında yemek yapmalarına izin verilmemesi dolayısıyla yetersiz beslenmelerini belirtmişlerdir.

\section{Ekonomik sorunlar;}

Ankete katılan öğrencilere ekonomik konular ile ilgili verilen yargılara katılma dereceleri sorulduğunda anket cevaplarında öğrencilerin kısmen ekonomik olarak zorluk yaşadığı, Türkiye'deki yaşam maliyetlerinin geldikleri ülkeye kıyasla pahalı olduğu ve kısmen sağlı sigortası maliyetinin yüksek olduğunu belirtmektedir. "Öğrencilerin ekonomik sorunları vardır” hipotezi doğrulanmaktadır.

Yapılan mülakatta özellikle kendi imkânları ile okumak isteyen öğrenciler ekonomik olarak zorluk çektiklerini belirtmişlerdir. YTB burslusu öğrenciler dışarıda yemek yemek istemeleri (kültürel başlığında da belirtildi gibi öğrencilerin Türk yemeklerine alışamamaları söz konusudur) durumunda ekonomik olarak burslarının yetmediğini belirtmişlerdir. Bilhassa YTB burslusu öğrenciler yaz döneminde yurtlarda yemek verilmemesi dolayısıyla dışarıda yemek yemek durumunda kaldıkları ve yaz aylarında burslarının yetmediğini belirtmişlerdir.

\section{Psikolojik sorunlar;}

Ankete katılan öğrencilere psikolojileri ile ilgili verilen yargılara katılma dereceleri sorulduğunda anket cevaplarında öğrencilerin büyük çoğunluğunun aile özlemi içerisinde olduğu, ülkelerindeki arkadaşlarını özlediğini, memleketlerinden ayrı kalmanın kendilerini üzdüğünü, çevrelerindekilerle rahat ilişki kurduklarını belirtmişlerdir. "Öğrencilerin psikolojik sorunları vardır" hipotezi doğrulanmaktadır.

Yapılan mülakatlarda da öğrencilerin en fazla üzerinde durdukları konu aile ve memleket özlemi oluştur. Öğrenciler kendilerini bazen yalnız hissettiklerini ve gizli gizli ağladıklarını belirtmişlerdir. Afrika kökenli öğrenciler ise ten renklerinden dolayı hem öğrenci arkadaşları hem de halkın tavırlarını kendilerini rahatsız ettiğini söylemişlerdir.

\section{Akademik sorunlar;}

Ankete katılan öğrencilere akademik konular ile ilgili verilen yargılara katılma dereceleri sorulduğunda anket cevaplarında öğrencilerin en 
önemli probleminin dil (akademik anlamda) problemi olduğu görülmüştür. Buna rağmen öğrenciler aldıkları eğitimden memnun olduklarını belirtmişlerdir. "Öğrencilerin akademik sorunları vardır" hipotezi özellikle akademik dil konusunda öğrencilerin yaşadıkları problemler dolayısıyla doğrulanmaktadır.

Mülakatlarda da anket sonuçlarına benzer şekilde öğrencilerin en fazla belirttikleri sorun öğrencilerin özellikle sözel dersleri anlamakta zorlanmasıdır. Ayrıca öğrenciler yazılı sınavlarda da zorlandıklarını belirtmişlerdir.

\section{Sosyal sorunlar;}

Ankete katılan öğrencilere sosyal konular ile ilgili verilen yargılara katılma dereceleri sorulduğunda anket cevaplarında öğrencilerin Türkiye ve Sakarya'da yaşamaktan mutlu olduğunu görülmüştür. Bu anlamda "Öğrencilerin sosyal sorunları vardır" hipotezi doğrulanmamaktadır.

Mülakatta da öğrenciler Türkiye ve Sakarya'da yaşamaktan genel anlamda mutlu olduklarını söylemişlerdir. Öğrenciler şehirdeki halkın ve esnafin yabancı öğrencilere karşı tutum ve davranışlarının genel anlamda iyi olduğunu belirtseler de mülakatlarda öğrencilerin halk ve esnafla yaşadıkları olumsuz örneklere de rastlanmıştır. Öğrenciler bir sorunla karşılaştıklarında genellikle kendi memleketlilerinin ya da diğer uluslararası öğrencilerin kendilerine yardım ettiğini belirtmektedirler. Özelikle YTB burslusu öğrenciler Sakarya'da bir temsilcinin olması gerektiğini belirtmektedirler.

Öğrencilerin eğitimlerini yarıda bırakıp ülkelerine dönmeyi düşünüp düşünmedikleri sorulduğunda bu soruya ankete katılanların büyük çoğunluğu hayır demiştir. Çok az bir kısmı ise evet demiştir. Evet diyenlerin gerekçeleri sorulduğunda ise öğrenciler beklentilerinin karş1lanmamasının, maddi sıkıntının ve memleket özleminin bunda etkili olduğunu belirtmişlerdir.

Öğrencilerin \%92.4'ü ülkelerine döndüklerinde çevrelerindekilere Türkiye'de eğitim görmelerini tavsiye edeceklerini belirtmişlerdir. Bu ise önemlilik arz etmektedir. 


\section{2. Öneriler}

Araştırmada elde edilen bulgular çerçevesinde aşağıdaki öneriler yaprlabilir;

\section{Türkiye'nin tercih nedeni ile ilgili öneriler;}

Özellikle daha nitelikli öğrencilerin Türkiye'yi tercih etmelerinin sağlanmasında eğitim kalitesinin daha iyi vurgulanması, dini ve kültürel yakınlığın ön plana çıkarılması ve bilimsel başarıların daha fazla duyurulması önemlilik arz etmektedir.

\section{Arkadaşlık, dil ve iletişim ile ilgili öneriler;}

Uluslararası öğrencilerin Türkçe konuşmalarındaki aksaklıkların Türk öğrenciler tarafından dalga konusu yapılmaması ile ilgili Türk öğrencilere yönelik oryantasyon çalışmaları yapılabilir. Bu çalışmalar kamu spotları kullanılarak tüm Türkiye'ye yönelik üniversitelerin kendilerinin yapacak olduğu bilbord ve diğer yayınlarla ya da hocaların bizzat derslerde bu konuyu işleyerek yapılabilir. Bu sayede yabancı öğrenciler Türkçe konuşmada çekinmeyecekler ve en önemli sorunları olan dil problemini daha rahat halledebileceklerdir. Afrika ülkelerinden gelen öğrencilerin ten renklerinden dolayı yaşadıkları problemler de benzer uygulamalarla giderilebilir. Kıskançlık hissinin ortadan kaldırılması ile ilgili olarak yukarıda belirtilen yöntemler kullanılarak uluslararası öğrencilerin herhangi Türk gencinin hakkını çalmadığı, aksine bu öğrencilerin Türkiye için bir değer olduğu Türk öğrencilere anlatılmalıdır.

\section{Sağlık sorunları ile ilgili öneriler;}

Uluslararası ögrenciler her ne kadar sağlık konusunda ciddi problemler yaşamadıklarını belirtseler de sağlık hizmetleri konusunda da iyi bilgilendirilmedikleri düşünülmektedir. Öğrencilerin sağlık hizmetleri ile ilgili süreçler konusunda daha iyi bilgilendirilecekleri bir tanıtım faaliyeti yapılabilir. Kendi kaynakları ile okuyan öğrencilerin de sağlık sigortası konusunda Türkiye tarafindan desteklenmesi önerilebilir.

\section{Kültürel sorunlar ile ilgili öneriler;}

Uluslararası öğrencilerin hem kendi kültürlerine ait yemek özlemlerinin giderilmesi hem de yeterli ve sağlıklı beslenebilmeleri için kendilerine kaldıkları yurtlarda yemek yapma imkânı ve ortamı sağlanmalıdır. 
Öğrenciler tabldot şeklinde çıkan yemekleri yemeye ve kantinden beslenmeye zorlanmamalıdır.

\section{Ekonomik sorunlar ile ilgili öneriler;}

Kendi imkânları ile okumak isteyen öğrencilere yönelik bursa imkânlarının artırılması önerilebilir. YTB burslusu öğrencilere yaz döneminde yurtlarda yemek yeme imkânı sağlanması ya da burs miktarlarının yaz döneminde artırılması önerilebilir.

\section{Psikolojik sorunlar ile ilgili öneriler;}

Öğrencilerin aile ve memleket özlemlerinin azaltılmasında Türk öğrencilerin ve Türk halkının öğrencilere daha fazla yardımcı olması önerilebilir. Afrika kökenli öğrencilerin sorunları ile ilgili de arkadaşlık kısmında yapılan öneriler tekrarlanabilir.

\section{Akademik sorunlar ile ilgili öneriler;}

Öğrencilerin dil becerilerinin gelişmesinde arkadaşlık ile ilgili sorunlarının giderilmesi önemlilik arz etmektedir. Genellikle öğrencilere TÖMER'de dil öğrenmeleri için tanınan süre bir yıldır. Kuşkusuz bu süre dil becerilerinin ve akademik becerilerin gelişmesi için yeterli olmayabilmektedir. Akademik becerilerinin gelişmesinde ise TÖMER'de akademik bir eğitim almaları da önerilebilir. Bunun yanı sıra öğrencilere üniversitelerinde ek derslerin verilmesi önerilebilir.

\section{Sosyal sorunlar ile ilgili öneriler;}

Öğrencilerin şehir halkı ve esnafı ile ilgili yaşadığı olumsuz tecrübelerin azaltılması önemlidir. Öğrenciler bir sorunla karşılaştıklarında hem üniversite bünyesinde (üniversitenin bünyesinde uluslararası öğrencilere yönelik bir ofis olmasına rağmen bu ofisin etkin işlemediği düşünülmektedir) hem de şehirde öğrencilere yönelik faaliyette bulunan bir ofisin kurulması önerilebilir. Bu tarz bir ofisin açılmasının öğrencilerin sorunlarının ilk elden ve daha hızlı çözümünde etkili olacağı, programdan beklenen katkıyı ise artıracağı belirtilebilir. 


\section{Kaynakça}

Altunışık, Remzi, Recai Coşkun, Serkan Bayraktaroğlu ve Engin Yıldırım, (2010), "Sosyal bilimlerde araştırma yöntemleri: SPSS uygulamalı", Sakarya Yayınc1lk.

Alyılmaz, Semra, Nurşat Biçer ve İsmail Çoban (2015), "Atatürk Üniversitesinde Öğrenim Gören Kırgız Öğrencilerin Türkçe Ve Türkiye'ye Yönelik Görüşleri”, Uluslararası Türkçe Edebiyat Kültür Eğitim Dergisi, Say1:4/1, ss.328-338.

Arambewela, Rodney ve John Hall (2009), “An empirical model of international student satisfaction", Asia Pacific Journal of Marketing and Logistics, Cilt:21, Say1:4, ss.555-569.

Babadağ, Burcu, İlkay Çulha ve Nedime Köşgeroğlu (2014), "Bir Sağ l1k Yüksekokulu'nda Öğrenim Gören Yabancı Uyruklu Öğrencilerin Sağlık Alanında Karşılaştığı Sorunların Belirlenmesi”, Gümüşhane Üniversitesi Sağllk Bilimleri Dergisi, Cilt: 3(1), ss.622-631.

Bayraktaroğlu, Serkan ve Lale Mustafayeva (2010), “Türk Yüksek Öğretim Sistemi ve Türk Dünyası İlişkileri: Sakarya Üniversitesi'nde Eğitim Gören Yabancı Uyruklu Öğrenciler Örneği”, Journal of Azerbaijani Studies, ss. 223-239.

Beltekin, Nurettin ve Somayyeh Radmard (2013), “Türkiye'de Lisansüstü Eğitim Gören Uluslararası Öğrencilerinin Üniversiteye İlişkin Görüşleri”, Elektronik Sosyal Bilimler Dergisi, Cilt:12, Say1:43, ss.250-269.

Biçer, Nurşat, İsmail Çoban ve Sıddık Bakır (2014), “Türkçe Öğrenen Yabancı Öğrencilerin Karşılaştığı Sorunlar: Atatürk Üniversitesi Örneği”, Uluslararası Sosyal Araştırmalar Dergisi, Cilt:7, Say1:29, ss.125-135.

Can, Niyazi (1996), “Türkiye'de Yüksek Öğrenim Gören Yabancı Uyruklu Öğrencilerin Sorunları ve Örgütsel Yapı”, Erciyes Üniversitesi Sosyal Bilimler Enstitüsü Dergisi, Cilt:1, Say1:7, ss.503-512.

Coşkunserçe, Ozan ve Suzan Duygu Bedir Erişti (2017), "Uluslararası Öğrencilerin Kültürel Uyum Sürecine Yönelik Tasarım Tabanlı Araştırma Yaklaşımına Dayalı Çevrimiçi Oryantasyon Uygulamasının Geliştirilmesi”, Eğitim Teknolojisi Kuram ve Uygulama Dergisi, Cilt:7, Say1:1, ss.83-104.

Çağlar, Ali (1999), “Türk Üniversitelerinde Öğrenim Gören Türk Cum- 
huriyetleri ve Akraba Toplulukları Öğrencilerinin Sorunları", Amme İdaresi Dergisi, Cilt:32, Sayı:4, ss.133-169.

Çetin, Turhan, Ufuk Karakuş ve Bülent Aksoy (2012), "Yabancı Uyruklu Öğrencilerin Turizm ve Türkiye'nin Turizm Değerlerine İlişkin Algıları”, Uşsak Üniversitesi Sosyal Bilimler Dergisi, Cilt:5(3), ss.180-196.

Çöllü, E. Fazıl ve Y. Emre Öztürk (2010), “Türk Cumhuriyetleri, Türk Ve Akraba Topluluklarından Türkiye'ye Yüksek Öğrenim Görmek Amacıyla Gelen Öğrencilerin Uyum Ve İletişim Sorunları (Konya Selçuk Üniversitesi Örneği)", Journal of Azerbaijani Studies, ss. 284-292.

Evans, Catrin ve Keith Stevenson (2011), "The experience of international nursing students studying for a PhD in the U.K: A qualitative study", BMC Nursing, Cilt: 10:11, ss.1-13.

Gökalp, Murat (2012), "19 Mayıs Üniversitesi Samsun Eğitim Fakültesinde Öğrenim Gören Türk Ve Yabancı Uyruklu Öğrencilerin Öğretim Programlarına Yönelik Bakış Açılarının İncelenmesi”, Elektronik Sosyal Bilimler Dergisi, Cilt:11, Say1:39, ss.139-152.

Göver, İbrahim Hakan ve Hasan Yavuzer (2015), “Kayseri’de Öğrenim Gören Yabancı Uyruklu Öğrencilerin Kayseri, Türkiye ve İslam Algısı", Turkish Studies, Cilt:10/2, ss.1025-1050.

Güçlü, Nezahat (1996), "Yabancı Öğrencilerin Uyum Problemleri”, Hacettepe Üniversitesi Eğitim Fakültesi Dergisi, Sayı:12, ss.101-110.

Güleç, İsmail ve Bekir İnce (2013), "Türkçe Öğrenen Yabancıların Günlük Yaşama İlişkin Kültürel Algıları Üzerine Bir Araştırma", Sakarya University Journal of Education, Cilt:3/3, ss.95-106.

Gülnar, Birol (2011), "Yabancı Öğrencilerde Kültürleşme ve Medya Kullanımı", Global Media Journal, Cilt: 2, Say1: 3, ss.51-68.

Hellsten, Meeri ve Anne Prescott (2004), "Learning at University: The International Student Experience", International Education Journal, Cilt:5, Say1:3, ss.344-351.

Jenkins, John R. ve Fred Galloway (2009), "The adjustment problems faced by international and overseas Chinese students studying in Taiwan universities: a comparison of student and faculty/staff perceptions", Asia Pacific Education Review, Sayı:10, ss.159-168.

KB (T.C. Kalkınma Bakanlığı) (2014), "Yükseköğretimin Uluslarara- 
sllaşması Çerçevesinde Türk Üniversitelerinin Uluslararası Öğrenciler İçin Çekim Merkezi Haline Getirilmesi Araştırma Projesi”, Kalkınma Araştırma Merkezi, Ekim 2014.

Kesten, Alper, Kasım Kıroğlu ve Cevat Elma (2010), "Language and Education Problems of International Students in Turkey", Klrglzistan Türkiye Manas Üniversitesi Sosyal Bilimler Dergisi, Say1:24, ss.65-85.

Kıroğlu, Kasım, Alper Kesten ve Cevat Elma (2010), “Türkiye'de Öğrenim Gören Yabancı Uyruklu Lisans Öğrencilerinin SosyoKültürel ve Ekonomik Sorunları", Mersin Üniversitesi Ĕgitim Fakültesi Dergisi, Cilt:6, Say1:2, ss.26-39.

Köylü, Mustafa (2001), “Ondokuz Mayıs Üniversitesi İlahiyat Fakültesine Devam Eden Yabancı Uyruklu Öğrencilerin Fakülte Hakkındaki Düşünce, Sorun ve Beklentileri”, O.M.Ü. Ilahiyat Fakültesi Dergisi, Cilt: 12, Sayı:12-13, ss.131-153.

Kumcă̆ız, Hatice, Rahim Dadashzadeh ve Kamil Alakuş (2016), “Ondokuz Mayıs Üniversitesi’ndeki Yabancı Uyruklu Öğrencilerin Sınıf Düzeylerine Göre Yaşadıkları Sorunlar”, Ondokuz Mayıs Üniversitesi Eğitim Fakültesi Dergisi, Cilt:35(2), ss.37-50.

Lee, Jenny J. ve Charles Rice (2007), "Welcome to America? International student perceptions of discrimination", Higher Education, Say1:53, ss.381-409.

Musaoğlu, Büşra Nur (2016), “Türkiye'de Öğrenim Gören Uluslararas1 Öğrencilerin Entegrasyon Süreci”, Türk Dünyası Eğitim Araştırmaları Dergisi, Y11: 1, Sayı: 1, Nisan 2016, s. 12-24.

OECD (2014), Education at a Glance 2014: OECD Indicators, OECD Publishing. http://dx.doi.org/10.1787/eag-2014-en (Erişim 01.12.2016).

OECD (2016), Education at a Glance 2016: OECD Indicators, OECD Publishing, Paris. http://dx.doi.org/10.187/eag-2016-en (Erişim 01.12.2016).

Otrar, Mustafa, Halil Ekşi, Bülent Dilmaç ve Ahmet Şirin (2002), “Türkiye'de Öğrenim Gören Türk ve Akraba Topluluk Öğrencilerinin Stres Kaynakları, Başaçıkma Tarzları ile Ruh Sağlığı Arasındaki İlişki Üzerine Bir Araştırma”, Kuram ve Uygulamada Eğitim Bilimleri (KUYEB) Dergisi, Cilt:2/2.

Öner, Mutlu, Alpaslan İnce, Muammer Özbebit ve Mete Sipahioğlu 
(2011), "Türkiye'de Ortaöğretim Kurumlarında Okuyan Yabancı Uyruklu Öğrencilerin Yükseköğretime Geçiş Problemleri”, Uluslararası Yükseköğretim Kongresi: Yeni Yönelişler ve Sorunlar (UYK-2011), 27-29 Mayıs 2011, İstanbul, Cilt:3, Bölüm: XII, ss. $1700-1709$.

Özkan, Gökhan ve Meltem Acar Güvendir (2015), “Uluslararası Öğrencilerin Yaşam Durumları: Kırklareli Ve Trakya Üniversiteleri Örneği”, Abant İzet Baysal Üniversitesi Eğitim Fakültesi Dergisi, Cilt:15(1), ss.174-190.

Paksoy, H. Mustafa, Sadettin Paksoy ve Mehmet Özçalıcı (2012), "Türkiye'de Yüksek Öğrenim Gören Yabancı Uyruklu Öğrencilerin Sosyal Sorunları: GAP Bölgesi Üniversiteleri Örneği”, Kahramanmaraş Sütçü Imam Üniversitesi Iktisadi ve İdari Bilimler Fakültesi Dergisi, Cilt:2(2), ss.85-94.

Savaşan, Fatih (2015), "Renkli Kampüsler", PESA Görüş Yazısı, Şubat 2015. http://www.pesa.org.tr (Erişim 01.12.2016).

Şahin, Münir ve Hasan Demirtaş (2014), "Üniversitelerde Yabancı Uyruklu Öğrencilerin Akademik Başarı Düzeyleri, Yaşadıkları Sorunlar ve Çözüm Önerileri”, Milli Ĕgitim Dergisi, Sayı:204, ss. 88-114.

Tok, Mehmet ve Musa Yıgın (2013), "Yabancı Uyruklu Öğrencilerin Türkçe Öğrenme Nedenlerine İlişkin Bir Durum Çalışması”, Dil ve Edebiyat Eğitimi Dergisi, Sayı:8, ss.132-147.

Toker, Fevzi, Cemali Çankaya ve Mehmet Doğan (2003), "Uludağ Ünivesitesinde Öğrenim Gören Yabancı Uyruklu Türk Öğrencilerin Boş Zaman Etkinliklerine Katılımlarının Araştırılması", Uludağ Üniversitesi Eğitim Fakültesi Dergisi, Cilt:XVII, Sayl:1, ss.219-233.

Traş, Zeliha ve Hudayar Cihan Güngör (2011), “Avrupa Ülkelerinden Gelen Türk Asıllı Üniversite Öğrencilerinin Sosyal Destek ve Sosyal Bağlılıkları Üzerine Nitel Bir Araştırma", Selçuk Üniversitesi Sosyal Bilimler Enstitüsü Dergisi, Sayı:25, ss.263-271.

Yılmaz, Oğuzhan (2015), “Türkiye Türkçesi Öğrenen Kazakistanl1ların Karşılaştıkları Sorunlar”, TÜBAR-XXXVII-/2015-Bahar, ss.257-275.

Yiğit, Ruhi (2012), “Konya İlinde Öğrenim Gören Yabancı Uyruklu Üniversite Öğrencilerinin Temel Psikolojik İhtiyaçlarının Bir Kısım Değişkenler Bakımından İncelenmesi”, Selçuk Üniversitesi Sosyal Bilimler Enstitüsü Dergisi, Say1:27, ss.317-326. 